Maurer School of Law: Indiana University

Digital Repository @ Maurer Law

\title{
The Human Side of Public-Private Partnerships: From New Deal Regulation to Administrative Law Management
}

\author{
Alfred C. Aman \\ Indiana University Maurer School of Law, aaman@indiana.edu \\ Joseph C. Dugan \\ Indiana University Maurer School of Law
}

Follow this and additional works at: https://www.repository.law.indiana.edu/facpub

Part of the Administrative Law Commons

\section{Recommended Citation}

Aman, Alfred C. and Dugan, Joseph C., "The Human Side of Public-Private Partnerships: From New Deal Regulation to Administrative Law Management" (2017). Articles by Maurer Faculty. 2550.

https://www.repository.law.indiana.edu/facpub/2550

This Article is brought to you for free and open access by the Faculty Scholarship at Digital Repository @ Maurer Law. It has been accepted for inclusion in Articles by Maurer Faculty by an authorized administrator of Digital Repository @ Maurer Law. For more information, please contact rvaughan@indiana.edu. 


\title{
The Human Side of Public-Private Partnerships: From New Deal Regulation to Administrative Law Management
}

\author{
Alfred C. Aman, Jr.* EF Joseph C. Dugan ${ }^{* *}$
}

\begin{abstract}
During the New Deal era, Congress created a thenunprecedented program of economic and regulatory reforms, establishing independent agencies, and empowering them to shape and enforce pragmatic industrial policies. Twenty-first century regulation looks strikingly different from the New Deal vision. While New Deal agencies continue to perform some regulatory functions, market approaches have replaced many traditional command-and-control formulations, with private entities stepping in to perform tasks historically reserved to government.
\end{abstract}

Though govermment-by-contract is becoming the new normal, neither the Administrative Procedure Act ("APA") nor many of its state equivalents provide adequate guidance to ensure that individual rights are protected and democratic values preserved during these changing times.

This Article proposes a practical response to the outsourcing revolution: a new statutory framework derived from the elements of contract and directed toward public-private partnerships and contemporary delegations. If successful, our proposal would address the democracy deficit that inheres in the shadowy outsourcing processes that are common today; it would invite public stakeholders into the contracting process; and it would establish an essential safeguard for individual rights.

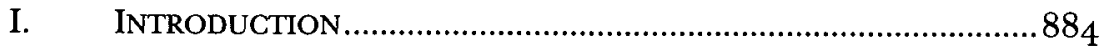

II. CONTRACTS AND THE ADMINISTRATIVE STATE ...........................88

A. GENERAL-SERVICE CONTRACTS AND PROCUREMENTS ................893

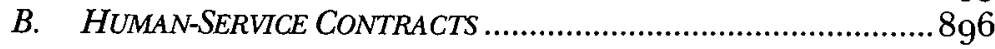

* Roscoe C. O'Byrne Professor of Law, Indiana University Maurer School of Law.

** J.D. 2015, Indiana University Maurer School of Law. Joseph previously clerked in federal district court and is currently clerking in the United States Court of Appeals. The authors wish to thank the editors of the Iowa Law Review, particularly Andrew Stanley, Judy He, and Reece Clark, for their assistance throughout the publication process. Many thanks as well to Professors Carol Greenhouse and Yvonne Cripps for their helpful comments. 


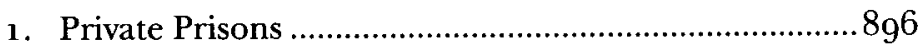

2. Provision for the Homeless ......................................902

3. Private Police and Paramilitary Forces .......................905

4. For-Profit Immigration Detention Centers and Private Repatriation ................................................906

5. Privately Administered Welfare Programs................... 908

C. CONTRACTING BEYOND THE SCOPE OF PERMISSIBLE DELEGATION................................................................ 912

III. A STATUTORY FRAMEWORK FOR HUMAN-SERVICE CONTRACTS .... 916

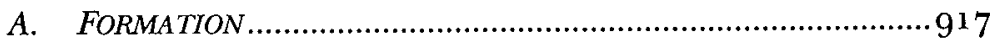

1. The Decision to Outsource ........................................ 917

2. Competitive Bidding ................................................ 918

3. Notice and Comment ............................................920

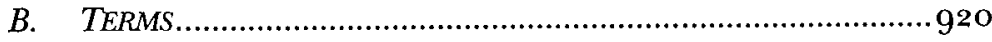

1. Definitions and Standards ........................................920

2. Liability ................................................................. 922

3. Duration, Revision, and Novation.............................. 923

4. Freedom of Information........................................ 924

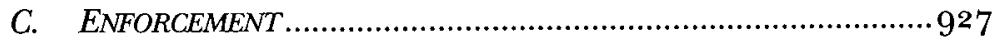

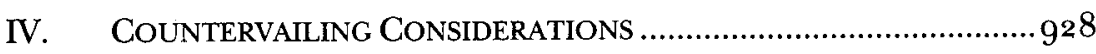

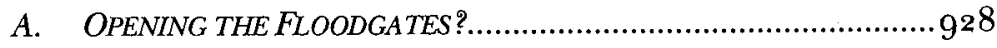

B. ELEVATED COSTS UNDERMINE EFFECTIVE DELEGATIONS?...........929

C. DUPLICATIVE LEGISLATION? .......................................... 931

V. THE FUTURE OF ADMINISTRATIVE LAW .................................933

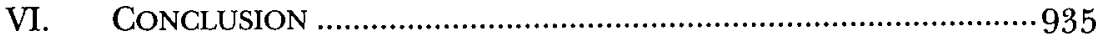

\section{INTRODUCTION}

During the New Deal era, Congress created what was, up to that point, "the most thoroughgoing program of reform in our history." Responding to massive market failures, monopolistic industries badly in need of oversight, ${ }^{2}$

1. Louis L. Jaffe, James Landis and the Administrative Process, 78 HARV. L. REV. 319, $3^{19}$ (1964). Landis was something of an administrative law "renaissance man," serving in turn as a member of the Federal Trade Commission ("FTC"), a member of the Securities and Exchange Commission ("SEC"), and, later, as the SEC commissioner. See generally JUSTIN O'BRIEN, THE TRIUMPH, TRAGEDY AND LOST LEGACY OF JAMES M LANDIS: A LiFE ON FIRE (2014).

2. See Ellis W. HaWley, The New DeAl and the Problem of Monopoly: A StUdy in ECONOMIC AMBIVALENCE 47-48 (1995) ("It was not competition that caused depressions, but rather the lack of it, the system of private monopolies that created violent inequalities in the distribution of income and destroyed the purchasing power of the masses."). 
and fledgling industries trying to take hold, Congress enacted a plethora of new statutes, created independent agencies, and imbued these agencies with the power to shape and enforce pragmatic industrial policies. ${ }^{3}$ These agencies represented more than a mere iteration of traditional executive power: indeed, as one of the primary architects of the New Deal, James Landis, observed, the administrative process conceived during this era granted agencies the "full ambit of authority necessary... in order to plan, to promote, and to police."4

Times have changed. Many if not most of the monopolistic and fledgling domestic industries that Landis described over 75 years ago have evolved into complex, decentralized enterprises, often multinational in scope. Most New Deal agencies continue to perform some regulatory functions, but market approaches to regulation have replaced many traditional command-andcontrol formulations.5 More important, globalization has embedded itself into the fabric of contemporary society through channels opened, in large part, by the neoliberalization of global markets. Technology has greatly enhanced the free flow of capital around the world. ${ }^{6}$

Transnational corporations can make private "production, financ[ing], and investment" decisions relatively free of direct state involvement and move "from location to location" without entrenching in local politics or exposing themselves to much local regulation.7

Neoliberalism, with its deregulatory bent and its emphases on free trade and open markets, has typified the "global era" of administrative law that first emerged in the $1980{ }^{8}{ }^{8}$ A mainstay of this era has been outright deregulation wherever possible, or the displacement of traditional governmental regulation with market approaches where deregulation is not possible. Part

3. See Jaffe, supra note 1 , at 321 .

4. James M. Landis, THE Administrative Process 15 (1938).

5. The environmental and health-and-safety era of regulation, beginning in the late 1960 , added another substantial regulatory layer to what had been created in the New Deal. AlfRed C. AMAN, JR., THE DEMOCRACY DEFICIT: TAMing GlobalizaTion THROUGH LAW REFORM 23-30 (2004).

6. "[T]oday's financial markets are globalizing rather than internationalizing ... since, for instance, the movement of capital has largely become independent of the sovereign control of state agencies." Jost Delbrück, Globalization of Law, Politics, and Markets-Implications for Domestic Law-A European Perspective, 1 IND. J. GLOBAL LEGAL STUD. 9, 10 (1993); see also David Albrecht, More on the Free Flow of Capital and IFRS, SUMMA (Mar. 7, 2009), http://profalbrechtwordpress.com/20o9/o3/o7/ more-on-the-free-flow-of-capital-and-ifrs ("Current economic orthodoxy is based on the internationalization of financial markets and free flow of capital across any and all national borders.").

7. See Alfred C. Aman, Jr., Proposals for Reforming the Administrative Procedure Act: Globalization, Democracy and the Furtherance of a Global Public Interest, 6 IND. J. GLOBAL LEGAL STUD. 397,408 (1 999 ).

8. Id. at 4 oo ("Deregulation and privatization [have been] widespread responses to the global economy throughout the West. On some occasions, deregulation in the United States involved the wholesale substitution of the market for regulation.... In other instances, deregulation involved the use of the market as a regulatory tool ...." (footnote omitted)). 
and parcel of this transition has been a dramatic expansion of outsourcing and public-private partnerships. Agencies form contracts with private parties; they specify terms at the outset, and they maintain degrees of supervisory authority. As a practical matter, however, it is the private contractors who deliver many of the services traditionally reserved to government.

To be sure, outsourcing is not a novel phenomenon. It is only natural that private contractors are well-suited to perform certain tasks-e.g., build roads, repair bridges, collect trash, and remove snow.9 We have, however, been witnessing not only a shift in the overall quantity of government contracts generally but also substantial qualitative differences in the kinds of governmental activities and responsibilities governments at all levelsfederal, state, and local-are willing to turn over to private providers. ${ }^{10}$ Contractors now manage immigration detention centers and private prisons; they disburse welfare benefits and operate utilities; they secure communities and investigate crimes." They have formed corporate entities to manage charter schools, augmenting traditional public education with a costcompetitive public-private hybrid. ${ }^{12}$ They have even been extensively involved in crucial aspects of military operations (including, though certainly not limited to, so-called "black ops").13

9. For a helpful discussion on the history of outsourcing, particularly at the municipal level, see Cristiane Carvalho Keetch, Trends in the Contracting Out of Local Government Services, UNIV. S. FLA. SCHOlar Commons: Graduate Theses \& Dissertations, Jan. 2013, at 39-47, http:// scholarcommons.usf.edu/cgi/viewcontent.cgi?article $=5902 \&$ context=etd. Indianapolis, Indiana (a city near and dear to the hearts of these authors), is particularly famous for its early-and comprehensive-approach to municipal privatization. See Eric Schnurer, When Government Competes Agcinst the Private Sector, Everybody) Wins, ATLANTIC (Mar. 11, 2015), http://www.theatlantic.com/politics/ archive $/ 2015 / 03 /$ when-government-competes-against-the-private-sector-everybody-wins $/ 387460$.

10. As Professor Aman notes in a recent essay on the legal aspects of globalization:

[A] primary area in which law is involved in globalization is in the administrative transfer of state functions to markets. "Privatization," "downsizing," "outsourcing," "contracting out," and other forms of marketization are properly considered among the dynamics of globalization, once these are understood in context. . . Indeed, the use of the private sector to deliver what once were governmentally provided services is a common form of privatization. Private contractors are pervasively involved in government functions, from military support to social services and myriad other roles. The primary governance tool in these cases is the contract.

Alfred C. Aman, Jr., Globalization: Legal Aspects, in INTERNATIONAL ENCYCLOPEDIA OF THE SOCIAL \& BEHAVIORAL SCIENCES 254, 258 (James D. Wright ed., 2d ed. 2015).

11. See infra Part II.B.

12. Some commentators have questioned whether a profit motive is compatible with $\mathrm{K}-1 \mathbf{2}$ education. See, e.g., Amy Baral, Charter Schools' Darker Side, SALON (July 6, 2012, 9:21 AM), http://www.salon.com/2012/o7/06/charter_schools_darker_side_salpart; Alan Singer, Why Hedge Funds Love Charter Schools, HUFFINGTON POST: BLOG, http://www.huffingtonpost.com/alansinger/why-hedge-funds-love-char_b_5357486.html-funds-love-charter-schools (last updated July 20, 2014 ); cf. Erik Kain, 8o\% of Michigan Charter Schools Are For-Profits, FoRBES (Sept. 29, 2011 , 1 1:51 AM), http://www.forbes.com/sites/erikkain/201 1/og/29/80-of-michigan-charter-school s-are-for-profits.

13. See infra notes 152-57. 
Though government-by-contract has increasingly become the new normal in a variety of contexts, the Administrative Procedure Act ("APA"), Congress's basic roadmap for rulemaking and adjudication in the administrative state, ${ }^{14}$ remains troublingly detached from these ubiquitous partnerships. ${ }^{15}$ Similarly detached are many of the "mini-APAs" and other procedural statutes crafted by state legislatures to control state agency practice. Often, these laws-enacted as they were in a period in which agencies wielded more centralized authority-offer little formal guidance with respect to contracting. ${ }^{6}$ The federal APA itself expressly exempts matters relating "to public property, loans, grants, benefits, or contracts" from the guidelines of notice-and-comment rulemaking. ${ }^{17}$ For state and federal agents contemplating, inter alia, private prisons or privately administered welfare systems, these laws offer few parameters: far from ensuring accountability and due process, they may be viewed by some as a carte blanche to contract, even where contracting implicates significant human rights concerns. ${ }^{18}$

This Article proposes a practical response to this migration toward contract: a new kind of statutory framework directed toward public-private partnerships and contemporary delegations. Our framework would not necessarily replace or subsume existing law, but it would complement and fill critical gaps in the APA and state administrative-procedure laws. The goal

14. Few statutory regimes have had a greater effect on the development of the law than the Administrative Procedure Act ("APA"). In a recent article, Kathryn Kovacs argued that the APA should qualify as a superstatute within the meaning of Bill Eskridge and John Ferejohn's theory: it emerged from a long period of deliberation; it altered regulatory baselines; it passed the test of time; and it broadly impacted the law, beyond the four corners of the statute itself. See generally Kathryn E. Kovacs, Superstatute Theory and Administrative Common Law, go IND. L.J. 1207 (2015).

15. It is worth noting that the Supreme Court may have a limited appetite for outsourcing, at least at the extremes. Many commentators speculated that the Court might reject a rulemaking delegation to Amtrak in a 2015 case, see Stephen Wermiel, SCOTUS for Law Students: Non-Delegation Doctrine Returns After Long Hiatus, SCOTUSBLOG (Dec. 4, 2014, 8:0o PM), http:/ /www.scotusblog .com $/ 2014 / 12 /$ scotus-for-law-students-non-delegation-doctrine-returns-after-long-hiatus. The Court ultimately resolved that case on less controversial grounds, ruling that Amtrak is a governmental entity for purposes relevant to the rulemaking at issue. See Dep't of Transp. v. Ass'n of Am. R.R.s., 135 S. Ct. $1225,1228(2015)$.

16. By contrast, some states have enacted statutes that specifically deal with privatization, although the constraints that these statutes place on agencies and the protections they carve out for stakeholders vary widely. See Alfred C. Aman, Jr., Privatization and Democracy: Resources in Administrative Law, in GOVERNMENT BY CONTRACT: OUTSOURCING AND AMERICAN DEMOCRACY 261, 272-83 (Jody Freeman \& Martha Minow eds., 2009) (cataloging various state statutory schemes); see also infra notes 220-32 and accompanying text (discussing the statutes).

17. 5 U.S.C. $\$ 553$ (a) (2) (2012). Some states have mini-APAs that closely mirror the federal language. See IND. CODE ANN. $\$ 4^{-21 \cdot 5-2-5(11) ~(2014) ~(" T h i s ~ a r t i c l e ~ d o e s ~ n o t ~ a p p l y ~ t o ~ t h e ~}$ following agency actions ... [t] he acquisition, leasing, or disposition of property or procurement of goods or services by contract.").

18. In fact, some mini-APAs go so far as to encourage privatization whenever feasible. See COLO. REV. STAT. $\$ 24^{-5} 5^{\circ}{ }^{\circ} 1$ (2016) (" $[\mathrm{I}] \mathrm{t}$ is hereby declared to be the policy of this state to encourage the use of private contractors for personal services to achieve increased efficiency in the delivery of government services...."). 
here is not to set back the clock or re-entrench in old solutions: the goal is to propose the key elements any new statutory approach to these issues should take; it is, in effect, to begin to codify a model of new governance befitting new relationships forged between public and private actors.

The Article proceeds as follows: Part II explores governance across three categories of delegations to the private sector-what we term general-service contracts, human-service contracts, and contracts arguably beyond the scope of permissible delegation. Part III develops our proposed statutory framework with respect to three aspects of public-private contracts: formation, terms, and enforcement. Part IV raises and responds to some countervailing considerations, while Part V concludes with some thoughts about the future of public-private partnerships in particular and administrative law more generally. A brief conclusion follows in Part VI.

\section{II. Contracts AND THE Administrative State}

The idea of delegations from agencies (themselves the recipients of delegated powers $)^{19}$ to the private sector is nothing new. ${ }^{20}$ Government has long recognized that some tasks are better suited for private actors, and agencies have relied on nongovernmental entities for basic services and procurements since the earliest days of the administrative state. ${ }^{21}$

But the public-private partnerships that have emerged over the past 20 years represent a very different kind of outsourcing. ${ }^{22}$ These contracts imbue

19. Robert J. Gregory, When a Delegation Is Not a Delegation: Using Legislative Meaning to Define Statutory Gaps, 39 CATH. U. L. REV. 725, 726 (1990) ("Congress routinely delegates rulemaking power to agencies, thereby inviting agencies to act in a legislative capacity and to promulgate standards when implementing a statutory scheme.").

20. See Gillian E. Metzger, Privatization as Delegation, $10_{3}$ CoLum. L. REv. 1367, 1369 (2003) ("Privatization is now virtually a national obsession. Hardly any domestic policy issue remains untouched by disputes over the scope of private participation in government .... Privatization is also endemic as a matter of administrative practice. Ours is a system in which private actors are so deeply embedded in governance that 'the boundaries between the public and private sectors' have become 'pervasive[ly] blurr[ed]." (alteration in original)).

21. See 5 U.S.C. $\$ 553$ (a) (2) (exempting contracts from the scope of notice-and-comment rulemaking). Although the Supreme Court banned delegations of legislative power to private entities in Carter v. Carter Coal Co., 298 U.S. 238 (1936), the delegations we are describing here do not involve the type of wholesale abdication that Carter Coal contemplated. Moreover, the Court has sanctioned a wide array of public-private enterprises over the years, signaling the limited vitality of Carter Coal. See Metzger, supra note 20, at $144^{\circ}$ ("[W] hile Carter's constitutional prohibition on private delegations ... remains alive in theory, it is all but dead in practice. Almost all private delegations are upheld. Courts are satisfied by formal provision for government ratification, however perfunctory.").

22. See infra Part II.B. Professors Aman and Greenhouse discuss the rise of this kind of outsourcing in a recent article. They describe the active promotion of outsourcing during the Reagan and Bush Administrations, the acceleration of outsourcing under George W. Bush's directive that federal agencies must privatize to the maximum extent possible, and the continuing vitality of outsourcing even in the comparatively pro-regulatory Obama Administration. See generally Alfred C. Aman, Jr. \& Carol J. Greenhouse, Prison Privatization and Inmate Labor in the Global Economy: Reframing the Debate over Private Prisons, 42 FORDHAM URB. L.J. 355 (2014). It is 
for-profit actors with substantial powers traditionally reserved to government: powers to manage the tasks of incarcerating, punishing, and-theoretically at least-also helping to rehabilitate criminal offenders; powers that directly affect the nourishment (or lack thereof) of the poor; and powers to house the homeless, deliver medical care to prisoners, and execute military operations. ${ }^{23}$

With the exception of contracts involving inherently governmental activities, ${ }^{24}$ we recognize that some of these partnerships may be essential for effective 21 st-century governance. ${ }^{25}$ Therefore, we do not argue that this transformation is necessarily good or bad. This is not an Article about the hazards or improprieties of outsourcing. ${ }^{26}$ Public-private partnerships do not inherently violate legal or normative principles.

worth noting here that, to whatever extent the Obama Administration placed a hiatus on some deregulatory or delegation efforts, the incoming Trump Administration will very likely accelerate such efforts-making our proposals here perhaps even more timely than we had anticipated when we first conceived this Article. See, e.g., Nick Timiraos \& Andrew Tangel, Donald Trump's Cabinet Selections Signal Deregulation Moves Are Coming, WALL STREeT J. (Dec. 8, 2016), http://www.wsj.com/articles/donald-trump-cabinet-picks-signal-deregulation-moves-are-coming -1481243006 .

23. See infra Part II.B.

24. Inherently governmental activities, as defined by the Office of Management and Budget ("OMB"), are activities "so intimately related to the public interest as to mandate performance by government personnel." OFFICE OF MGMT. \& BUDGET, CIRCULAR No. A-76, at A-1 (2003), http:// www.whitehouse.gov/sites/default/files/omb/assets/omb/circulars/ao76/a76_incl_tech_corr ection.pdf. For more on this important subject, see infra notes $146-48$ and accompanying text.

25. Given rapidly emerging technologies, evolving social norms and mores, legislative dysfunction in Washington and many state assemblies, and a lack of consensus as to governmental priorities other than cost containment, contracting makes perfect sense for contemporary agencies. Agencies must be nimble, self-aware, quick to adapt, and creative with the resources they harness and deploy. Contracts, with their ultimate flexibility, facilitate these needs. See Alexander Cooley, Outsourcing Authority: How Project Contracts Transform Global Governance Networks, in Who Governs ThE Globe? 238, 241 (Deborah D. Avant et al. eds., 2010) ("Contracts vary in their exact scope and terms. Six specific aspects of contracts-cost structure, completeness, duration, monitoring, performance sanctions, and renewal potential-can all shape the incentives of contracting organizations."); Ronald J. Gilson et al., Contract and Innovation: The Limited Role of Generalist Courts in the Evolution of Novel Contractual Forms, 88 N.Y.U. L. REV. $170,176-77$ (2013) ("In developing a contractual response to changes in the economic environment, parties will choose the mechanism by which their innovation will be best adapted to the particulars of their context... When markets are thick-in the sense that many actors face similar changes in their dealings and stand to benefit from concerted responses to them-the affected parties often will institutionalize their innovative contract forms and terms through collective action. ... When markets are thin and the actors few and scattered, parties facing similar problems cannot rely on collective action to institutionalize contractual innovation because the necessary scale is not present. In these circumstances, innovation occurs initially in bilateral relationships."); Gilson et al., supra, at 190-91 ("Contracting parties must be able to count on the state's enforcement monopoly if they are confidently to rely on novel forms of agreement Ideally, generalist courts should respond to exogenously induced innovations by enforcing the chosen methods of mutual cooperation on terms consistent with the arrangements themselves.").

26. Frankly, hazards also inhere in the conventional model of public services delivered by public agencies. For example, a New Yonk Times investigative report recently exposed frequent " $[\mathrm{b}]$ rutal attacks 
We do argue, however, that certain public-private arrangements, which involve important political judgments directly affecting the welfare of human beings, should be subject to administrative law and to the accountability, transparency, and opportunities for meaningful participation that come with it. This is particularly the case with the human-service contracts we discuss below, because these contracts directly impact vulnerable populationsprisoners, the poor, immigrants, and others who lack political power and who are underrepresented or ignored by most of the processes involved. Typical outsourcing processes exacerbate the powerlessness of these populations. These processes seldom allow for direct participation in the fundamental decision to use private providers in the first place, and they usually exclude vulnerable human stakeholders from weighing in on the ways these contracts are created and implemented.

It is also especially important to note that the resort to privatization and outsourcing in such contexts can easily mask the essentially political decisions involved. For example, a decision to outsource prisoner healthcare to private providers does not eliminate the fundamental political decisions involving just how much tax revenue we are willing to spend on these services. Similarly, quite apart from wanting programs to be carried out efficiently, how much wealth should we, as a society, allocate toward provision for the homeless or for welfare recipients? Too often the significance of such political judgments is lost in the initial decision to outsource, as if the mere choice to delegate to a private provider were all that is necessary to make an informed decision. ${ }^{27}$ Such judgments and the resources applied to them are political questions that need to be answered by public bodies, openly and directly, with input from all affected stakeholders, including those most directly affected. As we will show below, the least-cost-bidding competitions that many procurement

by correction officers on inmates - particularly those with mental health issues." Michael Winerip \& Michael Schwirtz, Rikers: Where Mental Illness Meets Brutality in Jail, N.Y. TIMES (July 14, 2014), http:// www.nytimes.com/201 4/o7/1 4/nyregion/rikers-study-finds-prisoners-injured-by-employees.html. The report revealed that, during an 1 1-month period, "129 inmates suffered 'serious injuries" at the hands of Department of Correction staff. Id. The point being: privatization does not unidirectionally impede rights, and the conventional model does not necessarily protect them. See Michael Schwirtz \& Michael Winerip, Correction Commissioner Calls Overhauling Rikers a Long, Heazy Lift; N.Y. TIMES (June 4, 2015), http://www.nytimes.com/2015/o6/o5/nyregion/with-new-commissioner -a-slow-turning-in-efforts-to-remake-rikers.html (" $[\mathrm{D}]$ ysfunction is so deeply embedded in the jail culture that, if [Mayor de Blasio] is serious about turning things around, he would need to work at it until the very day he leaves office.").

27. As just one example, consider privatized health care in New York City's detention facilities. While privatization netted some financial savings (at least in the short term), service delivery problems and a general lack of transparency became endemic-a clear case of privatization gone awry. See Alfred C. Aman, Jr., An Administrative Law Perspective on Government Social Service Contracts: Outsourcing Prison Health Care in New York City, 14 IND. J. GLobal LeGAL STUD. 301, 311-13 (2007). 
processes utilize are not adequate for the kinds of decisions inherent in a putative contract involving, for example, health care for prisoners. ${ }^{28}$

Moreover, there is no reason to limit outsourcing contract procedures to a competition based only on cost. The requests for proposals ("RFPs") involved can also be used to encourage competition among potential providers for new ideas that might, for example, reduce recidivism rates among private prisoners, represent substantial improvements in the education level of prisoners, or undertake creative rehabilitative measures.

In addition, private providers are often exempt from the Freedom of Information Act ("FOLA"). ${ }^{29}$ Moreover, the policies these private providers implement are not subject to standard rulemaking processes, $3^{\circ}$ nor does the due process clause necessarily apply to them unless the state action doctrine is triggered (a question that generally cannot be resolved without substantial litigation and concomitant expenditures).31 Even if due process does apply, the breadth and scope of that doctrine have been substantially curtailed by courts over the years, especially in prison contexts. $3^{2}$

Beyond any constitutional or FOIA issues that may arise, agencies should be required, as a matter of sound policy, to direct their attention to the individual rights of the parties who come under their jurisdiction when they turn to private actors, private incentive structures, or market solutions to carry out their regulatory obligations-lest such contracts and delegations dilute these protections. We distinguish between human services and other services of an impersonal or material nature, so as to avoid the inherent risk that "efficiency-based" approaches incentivize-i.e., commodifying the very people who are intended to be beneficiaries of the services. Basic human needs should not be treated as marginal costs. For example, when prisoners are transported from one private facility to another, based solely on the least-

28. See infra Part II.B.1.

29. See infra Part III.B.4.

3o. 5 U.S.C. $\$ 55^{1}(1)$, (5) (2012) (defining "rule making" as an "agency process for formulating, amending, or repealing a rule" and further defining "agency" as certain "authorit[ies] of the Government of the United States"); id. \$ 553 (a)(2) (expressly exempting "matter[s] relating to ... public property, loans, grants, benefits, or contracts" from the strictures of APA rulemaking).

31. Lugar v. Edmondson Oil Co., 457 U.S. 922, 936-37 (1982) ("As a matter of substantive constitutional law the state-action requirement reflects judicial recognition of the fact that 'most rights secured by the Constitution are protected only against infringement by governments,' ... Our cases have accordingly insisted that the conduct allegedly causing the deprivation of a federal right be fairly attributable to the State. These cases reflect a two-part approach to this question of 'fair attribution.' First, the deprivation must be caused by the exercise of some right or privilege created by the State or by a rule of conduct imposed by the State or by a person for whom the State is responsible.... Second, the party charged with the deprivation must be a person who may fairly be said to be a state actor." (quoting Flagg Bros., Inc. v. Brooks, 436 U.S. 149, 156 (1978))).

32. Sandin v. Conner, $5^{1} 5$ U.S. $47^{2}, 4^{8} 4-86$ (1995) (holding that the Due Process Clause accords no remedy to a prisoner who complained that he was improperly subject to disciplinary segregation because such discipline is not "atypical and significant hardship"). 
cost availability of a particular bed, such decisions may result in the transfer from one part of the country to another without sufficient regard for where the prisoner's family may be located, thereby eliminating important support structures for the individuals involved.33 The more abstract and narrowly cost conscious these decisions become, the more likely it is that the incommensurability of the values (in this example, family and profit) will be ignored in the decision-making processes involved. While fiscal prudence is, of course, a necessary factor in government decisions, even the most compelling economic justifications for "going private" do not eliminate the government's core responsibility for the public interest-security in the broad sense. Thus, we place a high value on public participation and accountability, especially when human beings are direct stakeholders (as the object of the services in question). The processes we recommend would provide a check on what might otherwise be decision-making processes focused exclusively on the "bottom line." From this perspective, a contract for provision of prison health care, for example, should specify a standard of care on par with that of the free population34-just as a contract for building a bridge assumes a commitment to durability and safety on par with the industry standard. It is for such reasons that we seek to differentiate what we shall call human-service contracts from those focused primarily on brick and mortar, administrative services. When direct human services are at issue, the people who are the recipients of those services should be considered stakeholders, or third-party beneficiaries. Personal dignity and the integrity of the body should be among the considerations that trigger the closer scrutiny we recommend for humanservice contracts. 35

Before we explore what such a framework might include and how it might operate, we first examine the types of public-private arrangements agencies routinely establish. We conceptualize agency contracting along a pyramid: At the base lie general-service contracts and procurements. Higher up along the pyramid lie the human-service contracts that are the primary focus of this Article's statutory proposal. At the pinnacle lie those contracts that may exceed the scope of permissible delegation altogether-either because they inappropriately transfer inherently governmental power to the private sector or because they excessively jeopardize individual rights.

33. See generally Shymeka L. Hunter, Note, More Than Just a Private Affair: Is the Practice of Incarcerating Alaska Prisoners in Private Out-of-State Prisons Unconstitutional?, 17 ALASKA L. REV. 319 (2000); Holly Kirby, Locked Up and Shipped Away: Interstate Prisoner Transfers E Industry, GRASSROOTS LEADERSHIP (Nov. 18, 2013), http://grassrootsleadership.org/locked-upand-shipped-away; Victoria Law, California Ships Prisoners Out of State To "Reduce" Its Prison Population, TRUTHOUT (Dec. 6, 2013), http://www.truth-out.org/news/item/20405-californiaships-prisoners-out-of-state-to-reduce-its-prison-population; Arjun Sethi \& Holly Kirby, Opinion, Incarceration Across State Lines, AL JAZEERA AM. (Feb. 12, 2014, $11: 00$ AM), http://america. aljazeera.com/opinions/2014/2/prison-overcrowdingaboonforprivateprisons.html.

34. See infra notes $69-78$ and accompanying text.

35. See infra note 54 and accompanying text. 
We then turn our attention to our proposed statutory framework, outlining some recommended requirements for human-service contractsthose delegations of power traditionally reserved to government, which directly and substantially impact individual rights of human beings, their nutrition, medical care, and living conditions. With such contracts, basic dignity of the person and the fundamental integrity of the body are at stake.

\section{A. GENERAL-SERVICE CONTRACTS AND PROCUREMENTS}

At the base of our pyramid lie traditional procurement contracts and similar agreements between agencies and private actors, such as contracts for the maintenance of facilities, the development of infrastructure, the deployment of logistics, and the acquisition of equipment. These contracts enable government to function, and they free up some agencies to focus on rulemaking, adjudication, and other regulatory activities that legislatures have charged them to perform.

Procurement contracts represent a substantial percentage of the federal government's annual outlay. $3^{6}$ In fiscal year 2007 , for instance, federal agencies spent nearly $\$ 460$ billion on procurements.37 The Department of Defense ("DoD") is responsible for most of these procurements: it spent over $\$ 330$ billion on procurements in 2007.38 By comparison, the Department of Health and Human Services spent nearly $\$ 14$ billion,39 the Department of Education and the Environmental Protection Agency ("EPA") each spent less than $\$ 1.5$ billion, $4^{\circ}$ and the Equal Employment Opportunity Commission spent around $\$ 54$ million. 4 $^{1}$ In 2013 , the top federal contractors were all wellknown corporate names: Lockheed Martin, with over $9 \%$ of the procurement

36. For federal-law purposes, procurement, also called acquisition, is defined in $4^{8}$ C.F.R. $\S 2.101(\mathrm{~b})(2)(2016)$ :
Acquisition means the acquiring by contract with appropriated funds of supplies or services (including construction) by and for the use of the Federal Government through purchase or lease, whether the supplies or services are already in existence or must be created, developed, demonstrated, and evaluated. Acquisition begins at the point when agency needs are established and includes the description of requirements to satisfy agency needs, solicitation and selection of sources, award of contracts, contract financing, contract performance, contract administration, and those technical and management functions directly related to the process of fulfilling agency needs by contract.

Id. (emphasis added).

37. Fed. Procurement data Sys.-Next Generation, Gen. Servs. admin., federat PROCUREMENT REPORT: FY 2007, at 1 (2007), https://www.fpds.gov/downloads/FPR_Reports/ Fiscal\%2oYear\% 202007/Agency\%2oViews.pdf.
$3^{8 .} \quad I d$. at 54 .
39. Id. at 118 .
40. Id. at $6 \circ, 71$.
41. Id. at 77 . 
budget; Boeing, with $4.6 \%$; and Raytheon, General Dynamics, and Northrup Grumman, each with contracts worth billions. $4^{2}$

Many of these governmental procurements are relatively uncontroversial. For instance, no one would seriously challenge an agency's authority to strike a deal with an outside vendor for onsite food services.43 But even where the contract's subject matter is straightforward, the need for accountability and public participation is an entirely different matter from the discretion of agencies to contract with private providers in the first place. There is always a need to ensure that the processes by which contractors are chosen are fair and not susceptible to corruption. The massive outlays at the DoD and other large agencies may trigger suspicion, particularly where the contracts are formed without competitive bidding. Moreover, for any contract, irrespective of subject matter, the cost may be substantial enough to warrant greater public participation (or at least a greater effort on the part of contracting agencies to publicize contract terms).44 Further, troubling questions arise as privatization takes on new forms in new contexts. For instance, the recent privatization of many municipal utility providers may raise concerns over

42. Fed. Procurement Data Sys.-Next Generation, Gen. Servs. Admin, Top 100 CONTRACTORS REPORT (2013), https://www.fpds.gov/downloads/top_requests/Top_10o_Co ntractors_Report_Fiscal_Year_2013.xls.

43. Cafeteria \& Rest. Workers Union, Local 473 v. McElroy, $3_{67}$ U.S. 886, 887-89 (1961) (cafeteria employee filed suit after forfeiting her badge to enter M\&M Restaurants, Inc., an establishment located on site at the Naval Gun Factory and operating under contract).

44. This is particularly so in light of current economic trajectories. The U.S. federal budget is illustrative: assuming that an increase in the individual or corporate income tax rates remains politically untenable, and assuming-optimistically-that no major crises such as the wars in Iraq and Afghanistan or the Great Recession of 2008 further deplete the government's coffers, the public debt is on track to equal $100 \%$ of GDP by 2038 . Lisa Mascaro, Federal Deficit Shrinking, But Long-Term Outlook Dim, LA. TIMES (Sept. 17, 2013), http://articles.latimes.com/2013/sep/17/news/la-pn-federaldeficit-shrinking-outlook-dim-20130917. A recent $\mathrm{CBO}$ report noted that, while annual deficits are likely to hover between $2.5 \%$ and $3 \%$ of GDP through 2018 , they will climb to around $4 \%$ in the years following, particularly if interest rates rise in the latter part of this decade (raising the government's borrowing costs). CONG. BUDGET OFFICE, THE 2014 LONG-TERM BUDGET OUTLOOK 7-8 (2014),

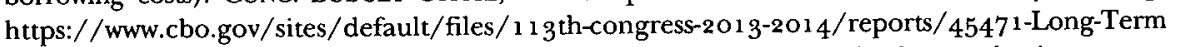
BudgetOutlook_7-29.pdf. Medicare and Social Security trust funds, though often used as instruments of political fear-mongering, are also in actual long-term jeopardy. Under current projections, the Medicare fund will be depleted in 2026, while the Social Security fund will run out in 2033. Medicare Will Be Exhausted in 2026, Social Security in 2033, CNBC (May 31, 2013, 12:25 PM), http://www.cnbc. $\mathrm{com} / \mathrm{id} / 100780248 \#$. Many states are in similarly precarious positions. See Io States with Enomous Debt Problems: Report, HUFFINGTON POST: BUS., http://www.huffingtonpost.com/201 2/o8/28/state-debtreport_n_1836603.html (last updated Oct. 28, 2012) (as stated by Bob Williams, President of State Budget Solutions, “[o]ur states are in trouble and no amount of budget gimmicks, political posturing or hiding bills will fix the massive debt that they face... Drastic reforms, innovations and political courage are needed to put our states back on the road to fiscal survival"). All this to say: when the government faces perennial shortfalls and the burden of long-term, accelerating debt, the public may have the right and the responsibility to weigh in on multibillion dollar acquisitions, particularly when the justification for those acquisitions seems thin. See David Axe, Pentagon's Big Budget F-35 Fighter 'Can't Tum, Can't Climb, Can't Run', REUTERS: GREAT DEBATE (July 14, 2014 ), http://blogs.reuters.com/ great-debate $/ 2014 / 07 / 14 /$ pentagons-big-budget-f-35-fighter-cant-turn-cant-climb-cant-run. 
affordable public access to essential services.45 The transition from publicly administered highways to privately operated toll roads may also trigger concern, especially if the funds generated from tolls do not result in improved infrastructure (e.g., fewer potholes and additional lanes of traffic).$^{6}$

In addition to those contracts with a potentially adverse impact on consumer access and affordability, some procurement contracts may implicate democracy concerns. Jennifer Nou, for example, has addressed the privatization of ballot counting, describing a "hybrid regime featur[ing] thousands of decentralized bureaucracies and a select group of private vendors that produce the equipment and requisite software to count millions of ballots." 47 Though Nou recognized the importance of technological innovation, she criticized a system characterized by a "lack of centralized coordination" and "little sense of shared best practices." $4^{8}$

General-service contracts can raise concerns, and these concerns warrant consideration. But for the most part, for the purposes of this Article, we leave these contracts to the expertise of agencies charged with carrying out their legislative directives.49 We turn our primary attention instead to those

45. See, e.g., Mike Gorrell, Eagle Mountain to Sell lts Gas, Electric Utilities, SALT LAKE TRIB. (June 4, 2014, 4:15 PM), http://archive.sltrib.com/story.php?ref=/sltrib/money/58026789-79/gas-electriceagle-mountain.html.csp; Danielle Ivory et al., In American Toums, Private Profits from Public Works, N.Y. TIMES (Dec. 24, 2016), http://www.nytimes.com/2016/12/24/business/dealbook/private-equitywater.html; Thom Nickels, A New Urban Crime: Selling Public Utilities to Private Conporations, HuFFINGTON POST: BLOG, http://www.huffingtonpost.com/thom-nickels/a-new-urban-crime_b_4979837.html (last updated May 21,2014 ).

46. The Future of Toll Roads in the U.S., NPR: DIANE REHM SHOW (Oct. 22, 2014, 10:00 AM), http://thedianerehmshow.org/shows/2014-10-22/future-toll-roads-us/transcript (discussing "how best to pay for highways and the future of toll roads"); see also Darwin Bondgraham, Highway Robbery: How "Public-Private Partnerships" Extract Private Profit from Public Infrastructure Projects, DOLLARS \& SENSE (2012), http://www.dollarsandsense.org/archives/2012/1112bondgraham.html (discussing the failure of the SR-91 toll project in Orange County, California).

47. Jennifer Nou, Note, Privatizing Democracy: Promoting Election Integrity Through Procurement Contracts, 18 YALE L.J. 744, 748 (2009). Jennifer Nou is now an administrative law scholar at the University of Chicago. A Biography of Jennifer Nou, U. CHI. L. SCH., http://www.law.uchicago.edu/ faculty/nou (last visited Jan. 5, 201 7).

48. Nou, supra note 47 , at $75^{\circ}$. Nou advocated "vigorous market incentives for innovation safeguarded by greater public inspection and transparency." Id. Specifically, she called for mandatory performance-based contractual provisions enforceable through the explicit designation of candidates as third-party beneficiaries to voting-machine procurement contracts. Id. at $75^{1}$.

49. Other scholars have devoted significant time and attention to these general-service procurements. See generally, e.g., Surya Gablin Gunasekara, The Balancing Act: Weighing National Security Against Equitable Procurement Practices, 20 FED. CIR. B.J. 569 (2011); Jim Moye, There Is Always a Better Way: Proposed Legislative Improvements for the Federal Procurement System, 14 RICH. J.L. \& PUB. INT. 307 (2010); Jennifer Jo Snider Smith, Competition and Transparency: What Works for Public Procurement Reform, 38 PUB. CoNT. L.J. 85 (20o8); Patrick J. DeSouza, Note, Regulating Fraud in Military Procurement: A Legal Process Model, 95 YALE L.J. 390 (1985); Lani A. Perlman, Note, Guarding the Government's Coffers: The Need for Competition Requirements to Safeguard Federal Government Procurement, 75 FORDHAM L. REV. 3187 (2007). 
contracts that implicate individual rights and liberties and complex human services decisions.

\section{B. HUMAN-SERVICE CONTRACTS}

Higher up our conceptual pyramid lie those contracts that represent nontraditional delegations or public-private partnerships-human-service contracts, the primary focus of this Article.

Human-service contracts touch on areas traditionally reserved to government. These areas implicate incommensurables. They affect human dignity and wellbeing, and as a result, they require heightened scrutiny, contestation, and accountability. As Professors Aman and Greenhouse have suggested, "[d]irect human vulnerability mandates more direct forms of public participation than those more impersonal domains of government contracts . . in which expenses and revenues may be more definitive." $5^{\circ}$

To formulate our concerns, we examine five categories of human-service contracts, providing illustrations for each: private prisons, schemes for homeless care, private police and paramilitary forces, for-profit immigration detention centers, and privately administered welfare programs.

\section{Private Prisons}

Contracts for private prison management offer a particularly apt example of the human-service contracts that most interest and concern us: $5^{1}$

On the one hand, [prisons] are buildings and workplaces like any other, servicing inmates as if they were clients-with clean laundry, occupations, education, and so forth. On the other hand, they are settings in which responsibility for the care of inmates-nutrition, medical care, basic life conditions-reach the level of human rights concerns. The former functions might easily be outsourced, but the latter - where the fundamental integrity of the body and the basic dignity of the person are at stake-pose more challenging questions..$^{2}$

In other words, the prison contract involves not one simple delegation but a variety of complex, interwoven responsibilities that must be carried out by government or private partners.53 Some of these responsibilities seem so

50. Aman \& Greenhouse, supra note 22, at 359 .

51. This is so because "[p]risoners-human beings with human needs-cannot reasonably be covered with the same sort of contract and contract processes that are used, for example, to construct a bridge or build a road." Id. at $405-06$.

52. Alfred C. Aman, Jr., Private Prisons and the Democratic Deficit, in PRIVATE SECURITY, PUBLIC ORDER: THE OUTSOURCING OF PUBLIC SERVICES AND ITS LiMITS 86, 86-87 (Simon Chesterman \& Angelina Fisher eds., 2009).

53. See Aman \& Greenhouse, supra note 22, at 358-59 ("The 'privatization of prisons' is a phrase that refers to many spheres of activity that are contractually separate and, in some ways ... conceptually distinct-as some involve direct substitution of private-for-public providers, whereas 
routine, so banal even, that no one would genuinely question the legitimacy of outsourcing-for instance, no commentator would seriously argue that agencies should assume direct responsibility for janitorial services or food preparation. But the prison context involves other, more sensitive services as well: security, nutrition, medical care, disciplinary review, and punishment. To what extent can and should these responsibilities be reallocated to private partners?54 And to what extent should those partners be constrained by administrative law?

Prisoners are uniquely vulnerable "beneficiaries" of government contracts: without the protections of due process and administrative procedure, and given the trend toward least-cost outsourcing, the risk is considerable that privately housed inmates will be treated as commodities, with inadequate attention devoted to their vital and very human interests.

These questions are particularly pressing due to the increasing application of traditional outsourcing techniques to cases involving the kinds of human issues we emphasize here: personal dignity and security. While the vast majority of correctional institutions were operated by government entities at government expense during the early part of the 2oth century, by the 1960 s prisons were increasingly reliant on private services.55 "The first modern privately-operated prison ... opened in $1976 \ldots$ In 1987 there were 3,100 inmates in private [prisons] worldwide; in 1998 that number had risen to $132,000 . " 5^{6}$

Why the rapid increase? Professors Aman and Greenhouse have suggested that, at the outset, before overcrowding became a serious concern, state authorities were motivated by prison-labor efficiency and self-financing opportunities.57 As prisoners earned money from their private-sector jobs, they could contribute much or most of it back to the prison as payment for their room and board. There also was, early on at least, a rehabilitative aspiration through job training for prisoners. Eventually, after privatization became a realistic alternative to traditional prison management, there was so much incarceration that states (as well as the federal government) looked for ways to lower the costs of building more prisons. $5^{8}$ Outsourcing to a private firm allowed the state to amortize its costs while the private provider put up

others involve reconfigurations of purposes and policies.").

54. At the extreme, in some jurisdictions, private entities — such as Sentinel Offender Serviceshave the power to issue warrants for probation violations and effectively (extrajudicially) extend sentences in response to such violations. Nicole Flatow, Private Probation Firm Illegally Extended Sentences, Judge Finds, ThINkPROGress (Sept. 24, 2013), http://thinkprogress.org/justice/2013/og/24/2666 401 / private-probation-firm-illegally-extended-sentences-judge-finds.

55. Alfred C. Aman, Jr., Privatisation, Prisons, Democracy and Human Rights: The Need to Extend the Province of Administrative Law, in PRIVATISATION AND HUMAN RIGHTS IN THE AGE OF Globalisation 91, 106-07 (Koen De Feyter \& Felipe Gómez Isa eds., 2005).

56. Id. at 106.

57. See Aman \& Greenhouse, supra note 22, 384-402.

58. Id. at $3^{88 \mathrm{n} .125 .}$ 
the necessary capital to build these new facilities in the first place-allowing the state to meet its obligations without raising taxes. 59

The authorizing legislation for privatization generally, and prisons in particular, is often sparse, and the agencies responsible for establishing these contracts are primarily tasked with cutting costs and spreading scarce resources as "efficiently" (sometimes thinly) as possible. ${ }^{60}$ Some statutes set forth cost-savings rationales for privatization of services; however, "as the costsavings requirement gets larger there is an increasing danger that private prisons would need to sacrifice prisoners' rights to meet the standard."61 There is recent evidence that just such sacrifices are being made in America's private prisons today. A June 2014 expose by the New York Times discussed the deplorable conditions at the privately run East Mississippi Correctional Facility, where "[o]pen fires sometimes burn unheeded," "[i]nmates spend months in near-total darkness," and the walls are "caked" with "[d]irt, feces and, occasionally, blood." 62 Conditions are not much better at the Lake Erie Correction Institution, a private prison operated by Corrections Corporation of America ("CCA"). There, a 2012 audit found that inmates lacked access to

59. Id. at 378-79.

6o. As Professor Aman noted in 20og:

There is a continuing debate about whether private prisons offer any real cost benefit. It is common, however, for some privatization statutes to require a minimum-percentage cost savings from private prison operators. Some states set a bar to outsourcing at a certain level of cost savings. While there would be little point in privatizing if some savings were not anticipated, the risks to prisoners' rights would seem to increase directly with the scale of the cost-savings requirement.

Aman, supra note $5 \mathbf{2}$, at 91 (footnotes omitted).

61. Aman, supra note 55 , at 108 . This obsession with savings is apparent in traditional staterun prisons as well as their private counterparts. In 2003, a writer for the Gadsden Times reported that the state of Alabama spent an average of just $\$ 0.91$ per prisoner per day on meals. Carla Crowder, Running Prisons on the Cheap, GADSDEN TIMES, http://www.gadsdentimes.com/news/ 20031201/running-prisons-on-the-cheap (last updated Dec. 1, 2003, 7:07 AM). Predictably, \$o.91 doesn't go very far: inmates at Kilby Prison described a particular dehydrated dish as "chicken explosion," among "many mysterious items" served with the goal of cutting costs. Id. More recently, infamous Maricopa County, Arizona, Sheriff Joe Arpaio boasted about a "special" Thanksgiving meal of vegetarian turkey soy casserole, clocking in at just $\$ 0.56$ per inmate. Shadee Ashtari, Joe Arpaio Offers Inmates, Fed Only Twice a Day, 56-Cent Thanksgiving Meal, HuFFINGTON Post: POLITICS (Nov. 27, 2013, 5:45 PM), http://www.huffingtonpost.com/2013/11/27/joearpaio-thanksgiving_n_4351729.html. On less "special" occasions, Arpaio feeds inmates only twice daily, and he eliminated "salt and pepper' to save taxpayer money." Id. Of course, many prisons have gone much further than Arpaio-charging prisoners room and board for the pleasure of dining behind bars. See Lauren-Brooke Eisen, Paying for Your Time: How Charging Inmates Fees Behind Bars May Violate the Excessive Fines Clause, 15 LOY. J. PUB. INT. L. 319,319 (2014).

62. Erica Goode, Seeing Squalor and Unconcern in a Mississippi Jail, N.Y. TIMES (June 7, 2014 ), http://www.nytimes.com/2014/o6/o8/us/seeing-squalor-and-unconcern-in-southern-jail.html. 
running water and toilets, while complaints about prison gangs and violence doubled during the year after the State of Ohio contracted out to CCA. ${ }^{6} 3$

Inmate health care, at both traditional governmentally operated prisons and at privately operated facilities, is also the target of considerable outsourcing-and the results can be catastrophic. Take, for instance, Prison Health Services-an entity that moved aggressively into New York prisons during the late 1990 and early 200os. A 2005 report by the New York Times found that Prison Health repeatedly failed to deliver adequate care to inmates, "provok[ing] criticism from judges and sheriffs, lawsuits from inmates' families and whistle-blowers, and condemnations by federal, state and local authorities." ${ }_{4}$ In the years following the New York Times article, Prison Health rebranded itself as PHS Correctional Healthcare and, following a merger with a competitor, it now operates under the name Corizon Health. ${ }_{5}$ Yet "the sins of Corizon's [corporate] parents . . . are forever linked with the progeny of their merger." ${ }^{66}$ The problem may lie with the model itself: "[c]ompanies like Corizon provide healthcare in prisons and jails under the [health maintenance organization ("HMO")] model, with an emphasis on cutting costs-except that prisoners have no other options to obtain medical treatment except through the contractor."67 Prison Legal News recited a variety

63. Laura A. Bischoff, Audtors Uncover Problems at Private Prisons in OHio, Prison PRIVATIZATION ALERT, no. 9, at 15 (2013), http://aoce-online.org/wp-content/uploads/2013/ 01/privatization-alert-9.pdf. In a surprising move in August 2016, the Department of Justice ("DoJ") announced that it intends to end its use of private prisons: officials will either decline to renew expiring contracts or will substantially reduce their scope. Matt Zapotosky \& Chico Harlan, Justice Department Says It Wall End Use of Private Prisons, WASH. POST (Aug. 18, 2016), https://www.washingtonpost.com/ news/post-nation/wp/2016/o8/18/justice-department-says-it-will-end-use-of-private-prisons/?utm_ term=.b7d $11 \mathrm{~d} 3 \mathrm{e} 8 \mathrm{gdf}$. It remains to be seen whether this policy shift will stick, particularly given the changeover in the upper echelons of DoJ leadership as the Trump Administration assumes control in Washington in 2017 . It also remains to be seen whether state prison officials follow DoJ's example. Given the general trend toward broader privatization and hybrid public-private partnerships over the past two decades, we suspect that an expansive reversion to government-run detention facilities is unlikely. But see Joe Davidson, Will States Follow DOJ's Private Prison Move? Some Are Ahead of the Feds, CHI. TRIB. (Aug. 26, 2016, $11: 37$ AM), http://www.chicagotribune.com/news/nationworld/ct-justicedepartment-private-prisons-20160826-story.html ("While the impact on states of the Justice Department's private prison decision remains to be seen, the federal government's strong influence on prison policy was demonstrated with the 1994 crime bill. It contributed to a prolonged period of mass incarceration at the federal and state levels and increased use of for-profit facilities.").

64. Paul von Zielbauer, As Health Care in Jails Goes Private, ro Days Can Be a Death Sentence, N.Y. TIMES (Feb. 27, 2005), http://www.nytimes.com/2005/02/27/nyregion/27jail.html.

65. For an illustration of this change, see Company Overview of Conizon Health, Inc., BLOOMBERG, http://www.bloomberg.com/research/stocks/private/snapshot.asp (last visited Jan. 5, 2017), with Conizon Launches from Correctional Healthcare Menger, CoRIzon HEalTH (June 19, 2011 ), http://www. corizonhealth.com/Corizon-News/Corizon-Launches-From-Correctional-Healthcare-Merger 1.

66. Greg Dober, Corizon Needs a Checkup: Problems with Privatized Correctional Healthcare, PRISON LEGAL NEWS (Mar. 15, 2014), https://www.prisonlegalnews.org/news $/ 2014 / \mathrm{mar} / 1_{5} /$ corizon-needs-a-checkup-problems-with-privatized-correctional-healthcare.

67. Id. (emphasis added). For a discussion of the problematic health maintenance organization ("HMO") cost-cutting model, see WALTER M. CADETTE, REGULATING HMOS: AN 
of instances in which lapses by Corizon employees exacerbated prisoner health problems and contributed to premature deaths. ${ }^{68}$

Shields v. Illinois Department of Corrections, a 2014 case before the Seventh Circuit, illustrates the unfortunate consequences that may befall injured inmates in the private prison industry. ${ }^{69}$ It also serves as a compelling reminder that constitutional law may not accord the third-party recipients of delegated governmental services the same remedy to which those recipients might otherwise be entitled in a traditional agency context.

Earnest Shields, a former Illinois inmate who injured his shoulder while lifting weights, brought suit alleging that the private company that provides medical services for the Illinois Department of Corrections failed to provide him with prompt and adequate treatment. $7^{\circ}$ As a result, he "now suffers from a serious and permanent impairment that could have been avoided." $7^{11}$ Shields argued that the defendants showed deliberate indifference to his needs, a violation of the Eighth Amendment ordinarily redressable as against state actors through section $1983.7^{2}$

Writing for the panel, Judge David Hamilton observed that the "case illustrates the often arbitrary gaps in the legal remedies under section 1983 for violations of federal constitutional rights." 73 Shields may have been the victim of institutional neglect-perhaps even indifference-but current case law requires something more. Before the medical contractor itself could be found liable, Shields would have to prove that the contractor maintained an unconstitutional policy or custom: the doctrine of respondeat superior has no application under current section 1983 analysis.74 As for the contractor's employees, Shields would have to prove specific, identifiable indifferenceand because the Department of Corrections and its private health partners diffused responsibility for inmate care, "[n]o one doctor knew enough that a

Ethical Framework for Cost-EfFective Medicine, Jerome LeVy Econ. Inst. Bard C. Pub. POL'Y BRIEF, no. 47, at 7-1 2 (1998), http://www.levyinstitute.org/pubs/ppb47.pdf.

68. Dober, supra note 66.

69. Shields v. Ill. Dep't of Corr., $74^{6}$ F.3d 782 ( $7^{\text {th }}$ Cir. 2014).

7o. Id. at 785 .

71. Id. The facts of Shields were hardly anomalous: accusations of inadequate medical care rank among the most common of prisoner complaints. Administrative review boards and courts sometimes seem troublingly unsympathetic to these complaints. See Jennifer Nelson, COA: Standard of Care Same for All Doctors, IND. LAw. (Nov. 10, 2014), http://www.theindianalawyer. com/coa-standard-of-care-same-for-all-doctors/PARAMS/article/35640 (recounting the facts of Allen v. Hinchman, an Indiana case in which a Marion County trial court erroneously held that "doctors practicing in the prison system have a different standard of care than those practicing in the general population"); see also generally Allen v. Hinchman, 20 N.E.3d 863 (Ind. Ct. App. 2014) (reversing that erroneous decision).

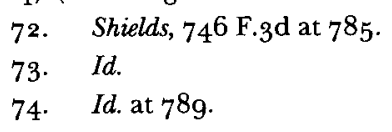


jury could find that he both appreciated and consciously disregarded Shields' need for prompt surgery." 75

While ultimately affirming the district court's grant of summary judgment to the defendants as required by circuit precedent, Judge Hamilton explained that the cases that exclude vicarious liability via section 1983 may "deserve fresh consideration," either by the Seventh Circuit sitting en banc or by the U.S. Supreme Court. $7^{6}$ Although the Supreme Court held in Monell $v$. Department of Social Services that "respondeat superior is not a basis for rendering municipalities liable under section $198_{3}$ for the constitutional torts of their employees,"77 the Court has never ruled that the Monell liability limitation also extends to private corporations acting under contract. Nevertheless, the Seventh Circuit and other appellate courts have drawn that extension. Judge Hamilton noted that Monell itself has come under heavy fire from commentators and dissenting Justices; moreover, because neither Supreme Court precedent nor the text of section 1983 requires courts to withhold employer liability, courts "should not insulate employers from respondeat superior liability under $\S 1983$ without powerful reasons to do so." 78

75. Id. at 786 . It is worth noting that Shields had at least a shot at pinning liability on the individual doctors responsible for his care; had the corporation not diffused responsibility, it is possible that the callous neglect of one or more doctors could have risen to the deliberate indifference standard. Conversely, had Shields been a federal prisoner, he would have been entirely out of luck: while section 1983 reaches both state officials and contractors acting under color of state law, there is no equivalent to the implied damages remedy of Bivens $v$. Six Unknown Named Agents of Federal Bureau of Narcotics, 403 U.S. 388 (1971), for suits brought against federal contractors or the facilities that employ them. See, e.g., Minneci v. Pollard, 132 S. Ct. 617,626 (2012) (requiring an inmate at a private federal prison to seek a state tort remedy rather than the Eighth Amendment Bivens remedy against prison officials); Corr. Servs. Corp. v. Malesko, 534 U.S. 61, 74 (2001) (declining to extend Bivens to damages actions against private entities acting under color of federal law); Alexander A. Reinert, Measuring the Success of Bivens Litigation and Its Consequences for the Individual Liability Model, 62 STAN. L. REV. 8og, 818-27 (2010) (examining the various limitations of Bivens claims); Allison L. Waks, Note, Federal Incarceration by Contract in a Post-Minneci World: Legislation to Equalize the Constitutional Rights of Prisoners, 46 U. MICH. J.L. REFORM 1065, 1074-78 (2013) (critiquing the state of the law). Of course, even apart from a Bivens remedy, a plaintiff may recover against a federal contractor if the plaintiff can fit his claims within the confines of some other cause of action, such as those arising under statute. Salim $\mathbf{v}$. Mitchell, No. CV-15-0286-JLQ, 2016 WL 1717185 , at *9 (E.D. Wash. Apr. 28, 2016) (allowing action against psychologists who allegedly implemented CIA torture program, brought pursuant to the Alien Tort Statute, to proceed to discovery).

76. Shields, $746 \mathrm{~F} .3 \mathrm{~d}$ at 789 .

77. Monell v. Dep't of Soc. Servs., $43^{6}$ U.S. $65^{8,} 66_{3}$ n.7 (1978) (emphasis omitted).

78. Shields, $74^{6} \mathrm{~F} .3 \mathrm{~d}$ at 792 (emphasis omitted). But for Seventh Circuit precedent, the panel would have reversed the district court's grant of summary judgment for the defendants. Although the medical contractor had diffused responsibility within its organization such that no single doctor or health professional could be individually liable for Shields's maltreatment, respondeat superior would enable courts to pin liability on the real culprit-the entity itself. Id. at 795 (" $[\mathrm{I}] \mathrm{n}$ a world of increasingly privatized state services, [respondeat superior] could help to protect people from tortious deprivations of their constitutional rights."). 
Judge Hamilton's call for a reordering of the section 1983 doctrine could offer significant relief for the victims of constitutional torts in the publicprivate context. However, the application of Monell to private corporations is well settled among the circuits, and an extensive reevaluation seems unlikely (barring action by the Supreme Court).79

Apart from the harm that inmates may suffer at the hands of privatesector security personnel and healthcare providers, the increasing private management of correctional institutions is also pressuring the traditional system of probation and early release. Private-prison operators frequently include occupancy requirements in their contracts, requiring a certain number of inmates at all times (perhaps up to 9o\% capacity) regardless of whether crime is rising or falling. ${ }^{80}$ Once inmates are finally released from the confines of these disturbing environments, "poverty capitalism" follows them back to their communities: for instance, Sentinel Offender Services, a private supplier of case-management and alcohol/drug monitoring systems, "takes pride in the 'development of offender funded programs where any of [its] services can be provided at no cost to the agency." 81

\section{Provision for the Homeless}

Tackling the problem of homelessness has long been a commitment for federal, state, and municipal authorities. For instance, the United States Interagency Council on Homelessness works to "creat[e] a national partnership at every level of government and with the private sector to reduce and end homelessness ... while maximizing the effectiveness of the federal

79. In fact, the Seventh Circuit itself declined to rehear the Shields case en banc, with only Chief Judge Wood and Judge Hamilton voting in favor of rehearing. Id. at 782 .

8o. Bill Berkowitz, States Guarantee High Prison Populations for Private Prison Industry's Profits, BUZZFLASH (Oct. 1 1, 2013), http://truth-out.org/buzzlash/commentary/prison-populations-privateprofits/ 18248-prison-populations-private-profits; Andy Kroll, This Is How Private Prison Companies Make Millions Even When Crime Rates Fall, MOTHER JONES (Sept. 19, 2013, 12:43 PM), http://www. motherjones.com/mojo/2013/og/private-prisons-occupancy-quota-cca-crime; see also Kevin Johnson, Private Purchasing of Prisons Locks in Occupancy Rates, USA TODAY (Mar. 8, 201 2, $12: 37$ PM), http://usa today3o.usatoday.com/news/nation/story/201 2-o3-ol/buying-prisons-require-high-occupancy/ $53402894 / 1$ (discussing a controversial proposal submitted by Corrections Corporation of America ("CCA") to prison officials in 48 states, offering to buy prisons in exchange for such concessions as $20-$ year minimum occupancy rates of $90 \%$ ).

81. Thomas B. Edsall, Opinion, The Expanding World of Poventy Capitalism, N.Y. TIMEs (Aug. 26, 2014), http://www.nytimes.com/2014/o8/27/opinion/thomas-edsall-the-expanding-world-of-pover ty-capitalism.html. Edsall situated Sentinel's case-management and monitoring services within a broader trend toward shifting the costs of governmental services to the poor. Id. He acknowledged that "the cost of being poor has always been exorbitant," as unscrupulous landlords and creditors have developed a vulture-like ability to feed off of poverty. $I d$. What has changed is the extent to which municipalities and other governmental units now charge the poor for the "privilege" of participating in the criminal justice system-"offender-funded law enforcement." Id. For a comparison, see also Special Series: Guilty and Charged, NPR NEWS INVESTIGATIONS, http://www.npr.org/series/31 $3986316 /$ guilty-and-charged (last visited Jan. 5, 2017). 
government in contributing to the end of homelessness." ${ }_{2}$ The Department of Veterans Affairs maintains a resource division to assist homeless veterans with housing, job training, and health care. ${ }^{8_{3}}$ And the Stewart B. McKinney Homeless Assistance Act requires the Secretary of Housing and Urban Development ("HUD") to identify federal buildings and real properties that are currently underutilized and to develop criteria with respect to the suitability of such buildings for housing the homeless. ${ }^{84}$

Even as government has assumed responsibility for persons experiencing homelessness, it has also outsourced related services to private vendors. Not unlike private prisons, the outsourcing of these functions to the private sector also involves what we call human-service contracts. For example, in 1993, the Board of County Commissioners of Miami-Dade County established the Miami-Dade County Homeless Trust to administer proceeds of a one-percent excise tax on certain food and beverage purchases for the benefit of homeless persons in the county. ${ }^{85}$ In addition to tax revenues, the Miami-Dade Trust receives and manages grants from HUD and state agencies. ${ }^{86}$ As one commentator suggested, " $[\mathrm{t}]$ he creation of the trust and a public/private partnership in Miami has by no means eliminated the problems of homelessness in Miami-Dade County, but it is theoretically a model and a step in the right direction." 87 The Trust contributed to Miami-Dade's selection as one of six HUD model city initiative grantees. ${ }^{88}$

The Miami-Dade Trust represents a noteworthy hybrid partnership that delivers essential services to combat homelessness, but not all such outsourcing has been so successful. In 2008, the Department of Justice entered into a settlement agreement with the District of Columbia, resolving an investigation into widespread Americans with Disabilities Act ("ADA") violations at DC-area shelters, operated by contract with the Community Partnership for the Prevention of Homelessness. ${ }^{89}$ In 2011 , one of the largest nonprofit shelters in Los Angeles decided to abandon its government-funded

82. About USICH, U.S. INTERAGENCY COUNCIL ON HOMELESSNESS, https://www.usich.gov/ about-usich (last visited Jan. 5, 2017).

83. Ending Veteran Homelessness, U.S. DEP'T VETERANS AFFAIRS, http://www.va.gov/homeless (last visited Jan. 5,2017 ).

84. Stewart B. McKinney Homeless Assistance Act, Pub. L. No. 100-77, §501, 101 Stat. 482 , $509(1987)$ (codified as amended at 42 U.S.C. $\$ 11411(2012)$ ).

85. About the Homeless Trust, MIAMI-DADE COUNTY, http://www.homelesstrust.org/abouthomeless-trust.asp (last updated Oct. 28, 2016, 11:22 AM).

86. Id.

87. Susan R. Jones, Tackling Homelessness Through Economic Self-Sufficiency, 19 ST. LOUIS U. PUB. L. REV. 385,405 (2000).

88. Id. at 4 o6.

89. Fact Sheet: Settlement Agreement in U.S. v. District of Columbia, ADA.GOV (Dec. $1_{5}, 2008$ ), http://www.ada.gov/dc_shelter_factsheet.htm. 
programs because its costs were not consistently covered and its payments were severely delayed. $9^{\circ}$

In a 2008 study, Steven Cohen and William Eimicke of Columbia University's School of International and Public Affairs explored the incentives of contracting out to nonprofit organizations for essential human services, including homeless care. $9^{1}$ They identified several benefits: nonprofit organizations are mission-oriented; they are unconcerned with achieving a "return on equity or profit"; they are unencumbered by many civil-service and procurement rules; and they are replaceable in the event that services fall below an established baseline. $9^{2}$ But Cohen and Eimicke identified several drawbacks as well: it can be difficult to control nonprofit activities due to the organizations' own distinct sense of mission; the organizations tend to have "poorly developed ... budget[ary] and management information systems"; and " $[\mathrm{t}]$ he transaction costs of procuring and maintaining contracts" with the organizations may run high.93 Thus, in New York City, which has "developed a system of service provision to homeless families that is largely implemented through contracts with nonprofit service providers,"94 Cohen and Eimicke found a lack of comprehensive client needs management and inconsistent policies regarding quality of service. 95

The drawbacks that Cohen and Eimicke observe with respect to contracting out for homeless care parallel in some respects the challenges that arise in the context of private prisons..$^{6}$ In both scenarios, the contracting agency may have different incentives and objectives than its private partner (though private prisons are more likely to prioritize profit taking, while homeless-care providers may be motivated by ideological or perhaps religious principles). And in both scenarios, transaction costs-always difficult to predict at the outset of a new contracting venture-can run high. More fundamentally, both contexts involve delegation of crucial governmental services to private actors, raising questions about: (1) whether such delegations are appropriate and (2) if so, to what extent the public should play a role in the outsourcing process.

9o. Alexandra Zavis, Homeless Shelter to Drop Government-Funded Programs, L.A. Times (June 25, 2011 ), http://articles.latimes.com/201 1/jun/25/local/la-me-shelter-cuts-201 10625.

91. See generally Steven Cohen \& William Eimicke, Managing Reinvention: Contracting with Non-Profits in NYC's Homeless Program (Nov. 4, 2008) (unpublished manuscript), http://www. columbia.edu/ $\mathrm{sc}_{32} /$ documents/managingmg.pdf.

92. Id. at 3 .

93. Id. at $3-4$.

94. II. at 6.

95. Id. at $8-9$.

96. These problems also arise with for-profit immigration detention facilities. See infra Part II.B.4. 


\section{Private Police and Paramilitary Forces}

In the post $-9 / 11$ security state, with officials at all levels of government struggling to balance such interests as cost-effectiveness and privacy with the need for increasingly sophisticated security strategies, public-private partnerships have presented an attractive vehicle for increasing manpower in vulnerable areas and enhancing technology. Some proposals seem compatible with the human interests at stake in the policing context; others seem extreme.

In a 2014 article, Professor Karena Rahall described the recent and dramatic rise of public-private policing partnerships.97 Rahall explained that these partnerships come in two varieties: they may involve information sharing to enhance overall safety, or they may involve outsourcing of support services such as public-housing development safety patrols, emergency dispatching, towing of impounded vehicles, data entry, and forensics..$^{8}$ As of 2006, approximately $45^{\circ}$ of these partnerships existed nationwide. 99

Thus far, Rahall noted, attempts to wholly outsource a municipal police force to a private security entity have not succeeded, "but the idea has been considered, and given current trends, plans to sell off entire departments are likely not far from realization." 100 As a stopgap while the legal kinks of such extreme outsourcing are straightened out, some jurisdictions have adopted so-called business improvement districts ("BIDs")-urban revitalization models which "typically assess a tax on local business and property owners to fund supplementary neighborhood services including security."

More extreme than municipal police outsourcing to private security forces (though also further on the fringe of current discourse) are proposals for the state authorization of private paramilitary forces to support the mission of state police agencies and the National Guard.102 In 2011, a Montana legislator proposed the creation of a volunteer armed paramilitary

97. See generally Karena Rahall, The Siren is Calling: Economic and Ideological Trends Toward Privatization of Public Police Forces, 68 U. MIAMI L. REV. 633 (2014).

98. Id. at $648-49$.

99. Id. at 648 .

10o. Id. at 658 .

101. John MacDonald et al., The Privatization of Public Safety in Urban Neighborhoods: Do Business Improvement Districts Reduce Violent Crime Among Adolescents?, 47 LAW \& SOC'Y REV. 621,622 (2013). Additionally, "[a] 2001 survey of over $25^{\circ}$ BIDs across the United States found that 36 percent were 'very involved' in a range of security projects including the provision of supplementary private security guards, purchasing electronic security systems, and working closely with the city police force." Id. at 626 .

102. In a sense, these paramilitary proposals can be analogized to Vice President Cheney's proposal to deploy military troops to arrest U.S. citizens associated with ALQaeda-bypassing the Posse Comitatus Act and other checks on military abuse. See, e.g., Glenn Greenwald, The Cheney Plan to Deploy the U.S. Military on U.S. Soil, SALON (July 25, 2009, 5:26 AM), http://www.salon.com/2009/o7/ 25/military_4; Mark Mazzetti \& David Johnston, Bush Weighed Using Military in Arrests, N.Y. TIMES (July 24, 2009), http://www.nytimes.com/2009/o7/25/us/25detain.html. 
group to "fill the gap between community service organizations ... and to provide the state and its local communities with the ability to call upon trained and organized volunteers when necessary resources are otherwise unavailable." ${ }^{103}$ The Montana bill died in committee. A similar 2007 proposal in Arizona would have created a "Homeland Security Force" to supplement National Guard troops currently patrolling the border. ${ }^{104}$ The bill was vetoed by then-Governor Janet Napolitano; subsequent legislative attempts to create such a force, in 2011 and again in 2012 , failed. ${ }^{105}$

While doméstic paramilitary forces have not (yet) gained legislative traction, the use of armed private security contractors overseas has become far more prevalent since the launch of the wars in Afghanistan and Iraq. Given the sharp criticism these particular delegations have received, and given the high risk of abuse where nonmilitary entities are imbued with military powers in foreign, perhaps effectively stateless jurisdictions, ${ }^{106}$ we address these contract forces in Part II.C, along with other arrangements that are potentially (and arguably) beyond the scope of constitutionally permissible delegation.

\section{For-Profit Immigration Detention Centers and Private Repatriation}

Just as private entities-principally CCA and the GEO Group, Inc. ${ }^{107}$ operate prisons on behalf of state and federal corrections departments, ${ }^{108}$ such entities also operate detention centers on behalf of the Bureau of Immigration and Customs Enforcement ("ICE"), housing undocumented

103. H.R. 278, 62nd Leg., Reg. Sess. $\$ 22$ (Mont. 2011 ).

104. Tim Steller, Militias in Arizona Thrive Despite Lack of Authorizing Law, ARIZ. DAILY STAR (May 27, 2012), http://tucson.com/news/local/border/militias-in-arizona-thrive-despite-lackof-authorizing-law/article_o8 7 eg8b6-5 d8e-5e65-bag8-ec91 8a3og875.html.

105. Id.

1 06. This is not to suggest that abuses are necessarily the product of privatization. After all, public security forces and military units have certainly committed their share of atrocities throughout history. But the abuses flowing from the involvement of private firms in the Iraq War illustrate a particular hazard with outsourcing. In the chaos of military operations, private firms may bypass or frustrate the military's chain of command such that abuses which might otherwise be prevented or swiftly corrected go unchecked. See, e.g., Matt Apuzzo, Blackavater Guards Found Guilty in 2007 Iraq Killings, N.Y. TIMES (Oct. 22, 2014), http://www.nytimes.com/2014/10/23/us/blackwater-verdict.html; Matt Apuzzo, Ex-Blackwater Guards Given Long Terms for Killing Iraqis, N.Y. TimES (Apr. 13, 2015), http://www. nytimes.com/2015/O4/14/us/ex-blackwater-guards-sentenced-to-prison-in-2007-killings-of-iraqicivilians.html. For another illustration, see generally INDEP. PANEL TO REVIEW DOD DET. OPERATIONS, FINAL REPORT OF THE INDEPENDENT PANEL TO REVIEW DOD DETENTION OPERATIONS (2004), http:// permanentaccess.gpo.gov/lps $53245 /$ www.defenselink.mil/news/aug2004/d20040824finalreport.pdf (discussing the Abu Ghraib scandal and subsequent investigation).

107. In 2009, roughly half of Immigration and Customs Enforcement ("ICE") detainees were housed in private detention facilities. That same year, CCA spent nearly $\$ 20$ million on lobbying. GEO spent around a quarter of a million dollars. See DET. WATCH NeTwORK, THE INFLUENCE OF THE PRIVATE PRISON INDUSTRY IN THE IMMIGRATION DETENTION BUSINESS 2 ( 201 l ), http://www.detentionwatchnetwork.org/sites/default/files/reports/DWN\% 2oPrivate\% 20 Priso n\% 2oInfluence\% 2oReport.pdf.

108. See supra Part II.B. 1. 
immigrants who are working their way through the immigration appeals process or awaiting deportation. ${ }^{109}$ Immigration detention is big business for private actors: "In fact, civil immigration detention is credited with saving the private prison industry from the brink of bankruptcy by forcing federal immigration authorities to seek additional space in which to house [detainees]."110

Private immigration detention centers include the Stewart Detention Center in southern Georgia $\left(1,75^{2}\right.$ beds), ${ }^{111}$ the Elizabeth Detention Center in New Jersey (300 beds), ${ }^{112}$ the Eloy Detention Center in Arizona $(1,500$ beds), ${ }^{13}$ and a facility near Otay Mesa, California, which opened in 2015 $\left(1,482\right.$ beds). ${ }^{114}$ In a fascinating hybrid relationship, CCA also assumed responsibility for operations at the new South Texas Family Residential Center, a detention camp for undocumented female and child immigrants. ${ }^{115}$ However, this particular transaction did not involve a standard contract between CCA and the federal government. ${ }^{16}$ Instead, the facility is funded by ICE through payments to the town of Eloy, Arizona-Eloy channels the funds to CCA, which in turn pays Eloy for its accounting services. ${ }^{17}$ Ostensibly, the arrangement-an "Intergovernmental Services Agreement" - was designed to avoid competitive bidding requirements and speed up construction of the new facility. ${ }^{118}$

Private entities are also playing an increasingly significant role in deportation. Under federal law, hospitals that receive Medicare funding are required to attempt to stabilize all emergency patients regardless of their

109. Relatedly, the Federal Bureau of Prisons acknowledges that " $[\mathrm{t}]$ he majority of BOP inmates in private prisons are sentenced criminal aliens who may be deported upon completion of their sentence." Contract Prisons, FED. BUREAU PRISONS, http://www.bop.gov/about/facilities/ contract_facilities.jsp (last visited Jan. 5, 2017).

110. Spencer Bruck, Note, The Impact of Constitutional Liability and Private Contracting on Health Care Services for Immigrants in Civil Detention, 25 GEO. IMMIGR. L.J. 487, 491 (2011).

111. Stewart Detention Center, CCA, http://www.cca.com/facilities/stewart-detention-center (last visited Jan. 5, 2017).

112. Elizabeth Detention Center, CCA, http://www.cca.com/facilities/elizabeth-detentioncenter (last visited Jan. 5, 2017).

113. Eloy Detention Center, CCA, http://www.cca.com/facilities/eloy-detention-center (last visited Jan. 5, 2017).

11 4. Otay Mesa Detention Center, CCA, http://www.cca.com/facilities/otay-mesa-detentioncenter (last visited Jan. 5, 2017).

115. John Burnett, How Will a Small Town in Arizona Manage an ICE Facility in Texas?, NPR (Oct. 28, 201 4, 4:39 AM), http://www.npr.org/2014/10/28/35941 1 g80/how-will-a-small-townin-arizona-manage-an-ice-facility-in-texas.

$116 . \quad I d$.

1 17. Id.; see also Tanner Clinch, Prison in Texas Big Business for Eloy, PINAL CENTRAL: THE ELOY ENTERPRISE (July 7, 2016), http://www.pinalcentral.com/eloy_enterprise/news/prison-in-texasbig-business-for-eloy/article_6804ab34-43ce-1 1 e6-9f64-7f88 2a 5 c9 $18 \mathrm{c}$.html.

118. Burnett, supra note 115 . 
immigration status. ${ }^{19}$ Yet the federal purse closes as soon as undocumented patients are deemed stable-and privately operated hospitals, unable to recoup often massive expenses associated with long-term care, are confronted with the option of "medically repatriating" these patients. Specifically, one study notes:

In an effort to save costs, and within the broader context of the privatization of immigration regulation and increasing immigration enforcement by local actors, many public and private hospitals take it on themselves to enforce the nation's immigration laws by deporting desperately ill immigrants directly from their hospital beds. In this new frontier of privatized immigration enforcement, hospitals act unilaterally or in concert with private transport companies to deport seriously ill or catastrophically injured migrants. ${ }^{120}$

The authors of one study documented "over 8 oo cases of successful or attempted medical repatriation" between 2007 and $2013 .{ }^{121}$ Because the process "takes place in the shadows without any governmental regulation,"122 the actual number of such repatriations may be higher.

\section{Privately Administered Welfare Programs}

Economist Peter Self describes the "welfare state" as those "basic services-principally social security, health, education and to some extent housing and transport-which should be made available to all citizens." ${ }^{23}$ The welfare state also encompasses economic rights (e.g., employment opportunities, minimum wage, and workplace protections). ${ }^{124}$ The welfare state arose during the middle of the last century, but it came under attack as the century wound down-with critics challenging its rising costs, its rigid and inflexible services, and its arguable failure to achieve greater equality. ${ }^{125}$

119. See 42 U.S.C. $\$ 1395$ dd(b) (2012); Special Responsibilities of Medicare Hospitals in Emergency Cases, $4^{2}$ C.F.R. $\$ 489.24$ (2016).

120. Lori A. Nessel, Disposable Workers: Applying a Human Rights Framework to Analyze Duties Owed to Seriously Injured or Ill Migrants, 19 IND. J. GLOBAL LEGAL STUD. 61, 63-64 (201 2) (footnote omitted).

121. Emily Orloff, Unconstitutional Medical Repatriation, IMMIGRATIONPROF BLOG (Apr. 25, 2013), http://lawprofessors.typepad.com/immigration/2013/o4/unconstitutional-medical-repatriation. html; see also SETON HALL UNIV. SCH. OF LAW'S GTR. FOR SOC. JUSTICE \& N.Y. LAWYERS FOR THE PUB. INTEREST, DISCHARGE, DEPORTATION, AND DANGEROUS JOURNEYS: A STUDY ON THE PRACTICE OF MEDICAL REPATRIATION 3 (2012), http://www.nylpi.org/images/FE/chain234siteType8/site203/ client/FINAL \% 20MED\%2oREPAT\% $\%$ oREPORT\%2oFOR\% 20 WEBSITE.pdf.

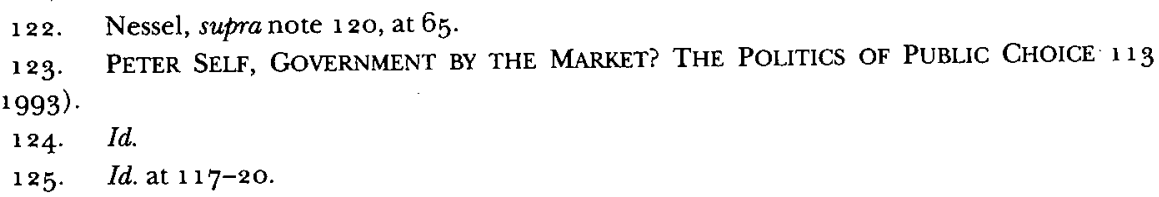


In response to such criticism, and in the context of broader neoliberal deregulation, welfare services at all levels-municipal, state, federal-have shifted to the private sector. Professor Self describes four incarnations of this shift:

1. Contracting out: "the state hires private providers to deliver some service but retains full financial and political responsibility for the outcome":;26

2. Voluntary agent approach: the state contracts with private providers to perform certain functions, while retaining oversight powers; ${ }^{127}$

3. Mandatory agent approach: the state requires private entities to perform services, while retaining some responsibility for the outcome; ${ }^{128}$ and

4. Subsidy approach: the state incentivizes private actors to perform services, but retains only "indirect responsibility for the outcomes." 129

During the mid-2ooos, the State of Indiana embarked on a privatization project in line with Self's second incarnation. The idea was to replace traditional caseworkers with a "remote eligibility" model, whereby claimants could apply for benefits and complete related transactions through remote call centers.' ${ }^{180}$ The State would theoretically retain policymaking authority and an operational role in the "modernization project," but private vendors would develop the infrastructure and (eventually) administer portions of the system. ${ }^{131}$

A coalition of companies led by IBM and Affiliated Computer Systems ("ACS") rose to the challenge, and the State awarded a contract to that coalition in 2006. ${ }^{13^{2}}$ The contract proved disastrous, almost from the start. Software malfunctioned, calls went unanswered, and thousands of Hoosiers had their Medicaid and SNAP benefits suddenly and erroneously terminated. ${ }^{133}$ The timing was particularly problematic, as the IBM coalition began assuming administrative control over welfare claims in 2007, just one short year before the Great Recession. ${ }^{34}$ Although no one reasonably could

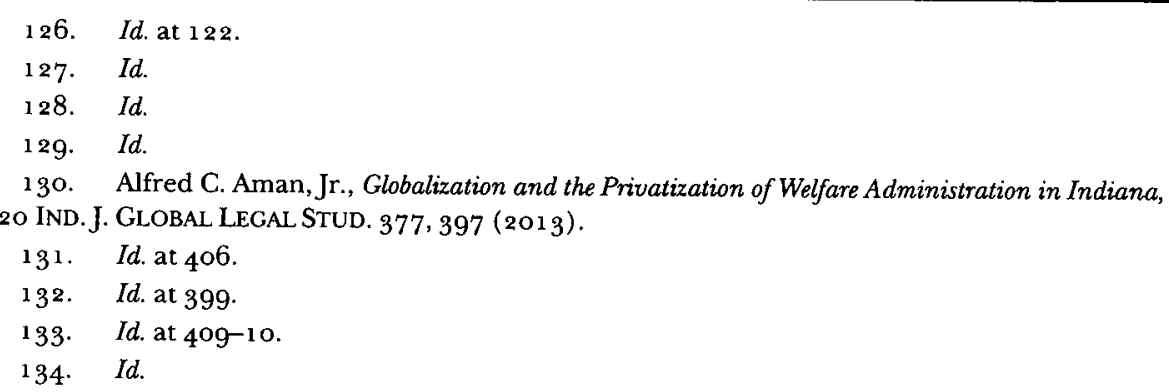


have foreseen the extent to which home losses and rising unemployment would further burden the strained welfare system, the IBM coalition was utterly unprepared to deal with those recessionary ramifications.

Governor Mitch Daniels canceled the IBM contract in 2009 while granting ACS "a new eight-year contract worth $\$ 6_{3} 8$ million." ${ }_{135}$ IBM and the State of Indiana sued one another; a state superior court awarded $\$ 52$ million to IBM in 2012, but the Indiana Court of Appeals reversed and remanded in early 2014 for a "determination of damages suffered by the state." ${ }_{136}$ On August 8, 2014, the Indiana Supreme Court announced that it would review the decision; ${ }^{137}$ the court heard oral argument that October. ${ }^{13^{8}}$ Finally, in March 2016-more than six years after litigation commenced-the Indiana Supreme Court ruled that IBM's collective breaches were material in light of the contract as a whole, and the court remanded to the trial court for an assessment of damages. ${ }^{139}$

The Indiana/IBM debacle raises at least three questions. First, was there something inherently wrong with the "modernization project" as conceived by the Daniels administration? If not, did the problem lie in the execution of the project-and if so, which party bears the blame for that? Finally, to the extent that state governments may continue to privatize their welfare systems, what lessons can be learned? In fact, many states have contracted with private parties for certain aspects of welfare benefits administration, often with mixed results. ${ }^{14^{\circ}}$

135. Matea Gold et al., Indiana's Bumpy Road to Privatization, L.A. TIMES (June 24, 2011 ), http://articles.latimes.com/201 1 /jun/24/nation/la-na-indiana-privatize-201 10624 .

136. Chris Sikich, Supreme Court to Consider IBM Welfare Privatization Case, INDYSTAR (Aug. 8, 2014, 1 2:15 PM), http://www.indystar.com/story/money/2014/o8/o8/supreme-court-consider-ibmwelfare-privitaztion-case $/ 13776633$.

137. Id.

138. Brandon Smith, Indiana Supreme Court Hears Oral Arguments in IBM Case, IND. PUB. MEDIA (Oct. 3o, 2014), http://indianapublicmedia.org/news/state-supreme-court-hears-oralarguments-ibm-case-7400o.

139. Indiana v. Int'l Bus. Machs. Corp., $5^{1}$ N.E.3d 150, 168 (Ind. 2016). Even after this landmark ruling, however, the controversy remained far from settled. In July 2016, the Indiana Supreme Court removed Judge David Dreyer, formerly the presiding trial judge, after the state accused him of bias and "exceed[ing] his [judicial] authority." See Dave Stafford, Justices Remove Dreyer from State v. IBM Case, IND. LAW. (July 5, 2016), http://www.theindianalawyer.com/justicesremove-dreyer-from-state-v-ibm-case/PARAMS/article/40801.

140. In 2005 , for instance, the Texas Health and Human Services Commission contracted with a private welfare management company to develop a new computer system and operate call centers, See Alex Cohen, Welfare 'Outsourcing' Hits a Snag in Texas, NPR (Aug. 22, 2006, 1:00 PM), http://www.npr.org/templates/story/story.php?storyld=5690044. Results were mixed: Although the program was allegedly on track to save hundreds of millions of dollars, welfare recipients complained about long hold times, misinformation, and improper benefit denials. Id. Seventeen states have also contracted with Xerox to administer their electronic benefit transfer systems. The Xerox platform, however, came under fire in October 2013, ironically during the much-maligned government shutdown, when a temporary computer "glitch" prevented shoppers from using their food stamp debit cards. See Mike Ludwig, Food Stamp Outage Highlights Problems with Privatization of 
Most welfare privatization is occurring at the state level, since most welfare programs are state administered (even if substantially federally funded). ${ }^{14^{1}}$ But some conservative politicians and (mainly conservative) commentators have argued for privatization within the federal government's two largest social welfare initiatives, Social Security ${ }^{14^{2}}$ and Medicare. ${ }^{143}$ While congressional defenders of the Social Security Administration have thus far resisted these calls to privatize, aspects of Medicare have gone private, most significantly with the Medicare Prescription Drug, Improvement, and Modernization Act of 2003 ("MMA"). ${ }^{144}$ As the overall state of contemporary

Public Services, TRUTHOUT (Oct. 18, 2013), http://truth-out.org/news/item/19481-food-stampoutage-highlights-problems-with-privatization-of-public-services. Other states have launched initiatives geared specifically toward child welfare. Florida privatized its foster-care system over a decade ago, while Kansas transferred the majority of its child-welfare services (including foster care, adoption, and family preservation) to private actors starting in the mid-1 99os. See Lisa Snell, Child Welfare Privatization Update, REASON Found. (Apr. 22, 2013), http://reason.org/news/ show/apr-2013-child-welfare-privatizatio. Nebraska followed suit with a privatization initiative in 2009:

Across the board, lawmakers, foster parents and child advocates now say Nebraska's privatization effort failed because it was ill-conceived, rushed, and inadequately funded. They also say often the caseworkers hired by the private companies had caseloads that were too heavy and in many cases did not have enough training to deal with the complexities of the welfare system.

Id.; see also, e.g., Kevin O'Hanlon, Privatization Fails: Nebraska Tries Again to Reform Child Welfare, GTR. FOR PUB. INTEGRIY (last updated May 19, 2014, 1 2:19 PM), http://www.publicintegrity.org/201 2/o8/ 21/10706/privatization-fails-nebraska-tries-again-reform-child-welfare; Deena Winter, Feds Demand Nebraska Repay \$22 Million for Botched Child Welfare Reform, NEB. WATCHDOG (Jan. 22, 2014), htt:// watchdog.org/124923/foley-repay-2 2-million.

141. Three core welfare programs, administered at the state level, rely in large part on federal block and matching grants. Compare Daniel Sutter, Welfare Block Grants as a Guide for Medicaid Reform 2-3 (Mercatus Ctr. at Geo. Mason U., Working Paper No. 13-07), http://mercatus.org/sites/default/files/Sutter_WelfareBlockGrants_v3.pdf (discussing the block grants that have funded TANF following Clinton-era welfare reform legislation), with LIZ SCHOTT ET AL., HOW STATES USE FEDERAL AND STATE FUNDS UNDER THE TANF Block GRANT, CTR. ON BUDGeT \& POL'Y PRIORITIES 18, 20-22 (Oct. 15, 2015), http://www.cbpp.org/sites/ default/files/atoms/files/4-8-15tanf_o.pdf (discussing recent legislative proposals to convert Medicaid and SNAP funding to the block-grant model).

142. See generally, e.g., Patricia E. Dilley, Taking Public Rights Private: The Rhetoric and Reality of Social Security Privatization, 41 B.C. L. REV. 975 (2000); Jerry W. Markham, Privatizing Social Security, 38 SAN DIEGo L. ReV. 747 (2001); Kathryn L. Moore, Partial Privatization of Social Security: Assessing Its Effect on Women, Minorities, and Lower-Income Workers, $6_{5}$ Mo. L. REV. $34^{1}$ (2000); Kathryn L. Moore, Privatization of Social Security: Misguided Reform, 71 TEMP. L. REV. 131 (1998).

143. See Bruce C. Vladeck, The Struggle for the Soul of Medicare, 32 J.L. MED. \& ETHICS 410,413 (2004) ("Consistent with conservative initiatives in other areas of social policy, such as education or job training, the most visible assault on Medicare's structure has been the promotion of privatization. ... The rhetoric may have died down, but the thrust to privatization of Medicare by pushing more and more beneficiaries into private plans has not.").

144. Medicare Prescription Drug, Improvement, and Modernization Act of 2003, Pub. L. No. 108-173, 117 Stat. 2066 (codified in scattered sections of 42 U.S.C. and 26 U.S.C.) [hereinafter "MMA"]; see also generally Robert I. Field \& Richard G. Stefanacci, Beyond Drug Coverage: The Cumulative Effect of Privatization Reforms in the Medicare Modermization Act, 1 ST. LOUIS 
governance continues to shift toward public-private partnerships and outsourcing, Social Security and Medicare privatization may gain political support in response to the precarious state of the trust funds. ${ }^{145}$ This possibility seems all the more real in 2017 , as Republicans assume control of Congress and the White House for the first time since 2006.

\section{CONTRACTING BEYOND THE SCOPE OF PERMISSIBLE DELEGATION}

The OMB Circular No. A-76, first issued in 1966 and most recently updated in 2003, purports to retain certain "inherently governmental" activities in-house-that is, within the agencies themselves. ${ }^{14^{6}}$ The circular explains that " $[\mathrm{a}] \mathrm{n}$ inherently governmental activity is an activity that is so intimately related to the public interest as to mandate performance by government personnel." ${ }^{447}$ Among the examples provided are activities that "[s]ignificantly affect[] the life, liberty, or property of private persons." $14^{8}$

While Circular A- 76 affords some guidance to agencies, important questions remain about the extent to which particular activities should qualify as inherently governmental. These questions have evoked discussion and debate among administrative law scholars. ${ }^{149}$

U. J. HEALTH L. \& POL'Y 207 (2007) (discussing the history of Medicare privatization and highlighting such MMA reforms as the conversion of Medicare Part C into Medicare Advantage and the introduction of health savings accounts).

145. Nancy Altman, Trump and Ryan Agree: Let's Dismantle Social Security, HUFFINGTON POST: BLOG, http://www.huffingtonpost.com/nancy-altman/trump-and-ryan-agree-lets_b_9992656.html (last updated May 16, 2016). But see generally JOSEPH WHITE, FALSE ALARM: WHY THE GREATEST THREAT TO SOCIAL SECURTTY AND MEDICARE IS THE CAMPAIGN TO "SAVE" THEM (2001) (suggesting that the compulsory nature of Social Security and the baseline safety-net function of Medicare are these programs' greatest assets; opposing privatization; and arguing instead for moderate reforms within the existing systems)

146. OFFICE OF MGMT. \& BUDGET, supra note 24, at A-1. The broader purpose of Circular A76 is to subject commercial (i.e., not inherently governmental) activities to public-private competitions in an effort to maximize efficiency and productivity. Id. However, A- 76 competitions have been suspended at the DoD-the agency with by far the greatest reliance on private contractors-since 2008. See VALERIE ANN BAILEY GRASSO, CONG. RESEARCH SERV., GirCULAR A76 AND THE MORATORIUM ON DOD COMPETITIONS: BACKGROUND AND ISSUES FOR CONGRESS 24 (2013), https://www.fas.org/sgp/crs/misc/R40854.pdf.

147. OFFICE OF MGMT. \& BUDGET, supra note 24, at A-2.

148. Id. The circular expressly excludes from the definition of inherently governmental activities the operation of "guard services, convoy security services, pass and identification services, plant protection services, or the operation of prisons or detention facilities." Id. at A-3 (emphasis added).

149. The questions are not uniquely American. As outsourcing and privatization have become commonplace in many advanced economies, scholars and jurists are grappling with the limits of permissible delegation under various constitutional frameworks. Results vary. In Israel, for instance, the High Court of Justice struck down legislation that would have established a privately operated prison, an unremarkable institution in American political society, as unconstitutional. See generally Barak Medina, Constitutional Limits to Privatization: The Israeli Supreme Court Decision to Invalidate Prison Privatization, 8 INT'L J. CONST. L. 690 (2010); see also generally Malcolm M. Feeley, The Unconvincing Case Against Private Prisons, 89 IND. L.J 1401 (2014) 
Professor Paul Verkuil has been a leading voice calling for restraint with respect to private participation in inherently governmental activities, particularly in the military context. Writing in 2006, Professor Verkuil noted that the "relationship of government to the private sector is very much in flux these days." $15^{\circ}$ He elaborated:

The number of private contractors doing the work of government has accelerated, while the number of federal employees needed to supervise them has eroded. This imbalance has negative consequences for public management generally, but it specifically makes surveillance of privatized activities an urgent matter. When combined with the loss of key government personnel, this lack of oversight and control becomes an inevitable consequence of privatization, producing imbalance between those in government who should oversee and those in the private sector who are meant to be overseen. ${ }^{151}$

Perhaps no category of delegation has generated more negative publicity in recent years than the use of private military and security companies ("PMSCs") in overseas operations. After all, one scholar has noted:

The relationship between governments and [PMSCs] can take a number of forms. PMSCs can be registered in one state and provide services to another state, for example, by assisting the armed forces of that other state.... Alternatively, PMSCs may be providing services to the armed forces of the state in which they are incorporated, whether at home or abroad. They may also be recruited by private actors, particularly corporations in need of better security than that which can be provided by the state on the territory of which they operate. ${ }^{15^{2}}$

Professor Angelina Fisher has observed that "[p] rivatization of security functions and proliferation of PMSCs have taken place without a corresponding outsourcing of accountability regimes." ${ }_{53}$ Whereas domestic

(rejecting the state monopoly theory against privatization in which the Israeli High Court anchored its decision).

150. Paul R. Verkuil, Public Law Limitations on Privatization of Government Functions, 84 N.C. L. REV. 397, 399 (2006) (footnotes omitted).

151. Id. at 399-400. Among those activities that should qualify as inherently governmental, Professor Verkuil has identified interrogation of prisoners, id. at $44^{1-42}$, and at least oversight of airport security, if not the function of TSA officers themselves. See Paul R. Verkuil, The Publicization of Airport Security, 27 CARDOZO L. REV. 2243, 2251 (2006).

152. Olivier De Schutter, The Responsibility of States, in PRIVATE SECURITY, PUBLIC ORdER: THE OUtsourcing OF PUblic Services AND ITS Limits 25, 25 (Simon Chesterman \& Angelina Fisher eds., 2oog).

153. Angelina Fisher, Accountability to Whom?, in PrIVATE Security, Public Order: The Outsourcing of Public Services ANd ITS Limits 46, 46 (Simon Chesterman \& Angelina Fisher eds., 2009 ). 
courts and administrative agencies supply U.S. persons with venues for airing grievances and seeking redress against domestically situated defendants, it is difficult to pin liability on PMSCs operating transnationally with a multinational work force: "An individual injured in Iraq by a Peruvian employee of a British PMSC may have a difficult time finding a forum in which to seek redress for injuries." 154 The problem is exacerbated when PMSCs operate (as they often do) in countries with weak governance structures. ${ }^{155}$

In a 2013 article, Professor Charles Tiefer proposed excluding PMSC contractors from such "high-risk" environments as personal security details and convoy security in areas of enemy strength. ${ }^{156}$ Current DoD rules bar contractors from activities closely related to combat, yet many warzone activities that fall short of organized campaigns still implicate significant human-rights concerns:

The years of use of [contractors] in Iraq and Afghanistan have shown the great harm that comes from allowing use of [contractors] for high-risk functions and only limiting combat functions. Local nationals are seriously alienated, government funds flow through [contractors] to warlords and the enemy, and [contractors] become especially remote from accountability when they are subcontractors or sub-subcontractors. ${ }^{157}$

Concerns over inherently governmental activities in zones of foreign conflict transcend the use of PMSC contractors on security missions. Commentators have also expressed concern about contract personnel who gather intelligence ${ }^{18}$ or who provide direct support in the "kill chain," the method of dynamic targeting that has become characteristic of 21 st-century warfare. ${ }^{159}$ And here at home, critics are wary of increasing reliance by the

154 Id. at 47; see also Cooley, supra note 25, at 257 ("In [Iraq], the adoption of cost-plus contracts, poor oversight, and a lack of central coordination and management led to nearly unchecked autonomy on the part of larger contractors.").

155. Fisher, supra note 153 , at 47 .

156. Charles Tiefer, Restrain "Risky Business": Treat High-Risk Private Security Contractors as Inherently Governmental, 5o HARV. J. ON LEGIS. 209, 213 (2013).

$157 \quad I d$. at 223 .

158. See Keric D. Clanahan, Wielding a "Very Long, People-Intensive Spear": Inherently Governmental Functions and the Role of Contractors in U.S. Department of Defense Unmanned Aircraft Systems Missions, 7o A.F. L. REV. $119,173-78$ (2013); Lindsay Windsor, Note, James Bond, Inc.: Private Contractors and Covert Action, 101 GEO. L.J. 1427, 1428-30 (2013).

159. "The standard [unmanned aircraft system] combat air patrol . . mission consists of six principal steps-find, fix, track, target, engage, and assess (F2T2EA), also known simply as the "kill chain." Clanahan, supra note $15^{8}$, at 165 . While contractors are precluded under current regulations from literally dropping bombs or launching missiles, they may play a robust role in the kill chain:

Providing tactical intelligence directly to ground troops to help them locate, track and engage enemy forces is clearly within the kill chain-without good intelligence, the commander is operating at a huge disadvantage.... Additionally, while precise 
nation's espionage services-the Defense Intelligence Agency, the Central Intelligence Agency, the National Counterterrorism Center, and the Pentagon's Counterintelligence Field Activity unit-on private contractors. ${ }^{160}$

This Article primarily aims to advance a statutory solution to cure the accountability deficit and the endangerment of individual rights inherent in human-service contracting; it is beyond the scope of this Article to precisely delineate which contracts represent constitutionally permissible delegations and which contracts may be impermissible. ${ }^{161}$

But however economically advantageous private contractors may be for the military or for other highly sensitive instrumentalities of the state, at least

targeting is regarded as an important, humane, objective, it is still direct support of combat activities. Similarly, using lasers to designate targets for strikes by manned aircraft or artillery is often the critical penultimate step before an attack. ... An overly constricted view of the kill chain would ignore the close connection [unmanned aerial vehicle ("UAV")] pilots, sensor operators, and laser designators can have to a combat role. Although the laser guided missile may be launched from another location, the laser emission or data coming from the UAV is often the key component to ensuring the missile strikes what the ground force commander needs to be taken out.

Id. at 184 .

16o. Simon Chesterman, Intelligence Services, in PRIVATE SECURITY, PUBLIC ORDER: THE OutSOURCing OF PUbliC SERVICES AND ITS LimITS $184,184-8_{5}$ (Simon Chesterman \& Angelina Fisher eds., 2009). Chesterman argues that three areas of intelligence privatization are particularly problematic because they involve private actors in inherently governmental activity: electronic surveillance, black ops detainee transport, and-most troublingly-interrogation. In the now-infamous Abu Ghraib scandal, although 12 uniformed personnel were convicted of various crimes, "[n]o charges have been laid against contractors, despite repeated allegations that they participated in abuse." Id. at 192.

161. For this reason, we are not prepared to itemize an exhaustive list of inherently governmental activities, though we certainly recognize that some activities must remain "in-house" regardless of the procedural protections that would constrain a private contractor. Cf. Paul R. Verkuil, The Nondelegable Duty to Govern, ADMIN. \& REG. L. NEWS, Spring 2006, at 4, 5 ("If the President assigns duties to private contractors that are normally performed by either principal or 'inferior' officers of the United States, the vertical dimension of separation of powers is triggered. Under Buckley $v$. Valeo, $4^{2} 4$ U.S. 1 (1976), officers of the United States exert 'significant authority'; this authority is inherent and exclusive to the executive function. Transfer of these kinds of functions to private hands, whether intentional or not, violates the authority delegated to the executive under the Constitution. For example, the President appoints military officers subject to senatorial concurrence. Their duties are within the constraints of the Constitution. When these officers conduct military operations they are exercising command authority. When private contractors perform these functions, such as interrogation of prisoners in Iraq, the constitutional connection is broken. Significant duties cannot devolve to private contractors under Buckley any more than they can be performed by congressionally appointed officials.").

Other highly sensitive, inherently governmental activities may include peacekeeping operations, see generally Chia Lehnardt, Peacekeeping, in PRIVATE SECURITY, PUBLIC ORDER: THE OUtSourcing OF PUblic Services AND ITS Limits 205 (Simon Chesterman \& Angelina Fisher eds., 2009); criminal prosecution, see Tyler Grove, Note, Are All Prosecutorial Activities "Inherently Governmental"?: Applying State Safeguards for Victim-Retained Private Prosecutions to Outsourced Prosecutions, 40 PUB. CONT. L.J. 991 (2011); and death penalty appeals, see Jan Pudlow, The Pros and Cons of Privatizing Death Penally Appeals, FLA. B. NEwS (Mar. 1, 2003), http://www.floridabar.org/DIV $\mathrm{COM} / \mathrm{JN} /$ jnnewso $1 . n s f / A r t i c l e s / 8 \mathrm{CEg}{ }_{3}{ }_{3} \mathrm{H}_{44}{ }^{2} 3_{3} \mathrm{CC}_{5}{ }^{2} 5^{6 \mathrm{CD}} 400739 \mathrm{EFC}$. 
some bright lines must be drawn to maintain collective decision making and collective implementation for those governmental activities that most profoundly implicate individual rights.

\section{A STATUTORY FRAMEWORK FOR HUMAN-SERVICE CONTRACTS}

Because neither the APA nor many state administrative-procedure statutes provide sufficient protection for individual rights in the types of human-service contracts discussed above, we turn our attention to an alternative: a new statutory framework that would preserve the flexibility of contracting and outsourcing while subjecting human-service contracts to heightened transparency and public-participation requirements. ${ }^{162}$ We think this solution makes sense, given that government-by-contract is so prevalent today. ${ }^{163}$ Agencies are much like many of the transnational corporations they regulate: they conduct their business through contracts, with an emphasis on relationship building. Our proposal would not undermine these contemporary norms; however, as we make clear, there are many issues that should remain public and subject to a new type of administrative law. To this end, we have modeled our statutory framework on the elements of a contract itself. Specifically, we have identified three focal points of human-service contracts. ${ }^{164}$ This approach presents three opportunities to ensure that delegations to private actors conform to the first principle of administrative law-preserving due process and protecting humanitarian values. ${ }^{165}$

The first focal point concerns contract formation. Specifically, we consider those factors that influence an agency to outsource in the first place and that weigh on the agency's choice to delegate in toto or to form an integrated partnership. We also consider which stakeholders should be entitled to participate in the process of bidding, drafting, and finalizing the agreement.

The second focal point concerns terms. Here, we consider which values and principles agencies ought to enshrine in their agreements, and what language they must include. We suggest that, with careful drafting guided by

162. Throughout this Part, we refer periodically to provisions of the ReNEUAL Model Rules on EU Administrative Procedure, and particularly to Book IV of those Model Rules (dealing with the intersection of administrative law and contract). We are indebted to Paul Craig, Professor of English Law at the University of Oxford and Visiting Professor at Indiana University Maurer School of Law, for bringing this document to our attention. For an online version of Book IV, see JEAN-BERNARD AUBY ET AL., RENEUAL MODEL RULES ON EU ADMINISTRATIVE PROCEDURE (2014), http://www.reneual.eu/ images/Home/BookIV-Contracts_online_version_individualized_final_2014-09-o3.pdf.

163. See, e.g., Aman, supra note 10, at 254; Metzger, supra note 20, at 1369 .

164. The discussion in this Part focuses on human-service contracts, as these contracts are of greatest interest and concern to us. The statutory framework we propose may have some application to general-service contracts and procurements-but the extent to which even those more traditional contracts warrant reform is largely beyond the scope of this Article.

165. For an early discussion on administrative law as a mechanism for vindicating due process, see generally Bernard Schwartz, Procedural Due Process in Federal Administrative Law, 25 N.Y.U. L. REV. $55^{2}$ (1950). 
statutory requirements, agencies can ensure that abstract terms such as "cost" and "value" are appropriately defined without hamstringing private actors or undermining the efficiency of the delegation. We also think that the content of contracts can be designed to protect individual rights while providing agencies and their partners with sufficient flexibility so that they are not compelled to recontract every time circumstances (or technologies) change.

The final focal point concerns enforcement. A contract is only as good as its execution, but the question most relevant to administrative lawyers should be, "who has the legal right to enforce the contract?" Obviously, the agency and its partners have a series of obligations and duties the breach of which could expose one or the other to liability. But agencies exist to effectuate the law of the land, and much of this law relates to individual rights. We suggest that the doctrine of third-party beneficiaries may have some application here. For instance, an administrative statute could endow a welfare recipient with standing to sue a private food-stamp processor for breach of contract. Or an inmate could be authorized to prosecute an action against a prison management corporation for the torts and deprivations brought about by its employees. Our statutory framework would establish a robust cause of action to vindicate righteous third-party claims. ${ }^{166}$ The following Subparts explicate our framework in detail.

\section{A. FORMATION}

\section{The Decision to Outsource}

When an agency first confronts the possibility that a private partner may be equipped to deliver better (or cheaper) human services than the agency itself could do, important decisions must be made. First, what are the problems that the agency is trying to solve? Is the agency merely after cheaper service, or does market competition bring with it a greater possibility of innovation as well? Second, who should be authorized to make the initial decision to outsource? The commissioner? A separate panel of decision makers within the agency? Stakeholders in the public sector? A mix of these individuals and positions? Do we need a process that involves multiple groups and input early on? 167

We here submit that, from the very outset, the public should have an opportunity to weigh in on the formation of, if not any public-private agreement, then certainly a human-service contract as characterized in Part

166. We recognize, of course, that authorizing litigation begets litigation. Our goal is certainly not to flood the courts. But we think that the costs of human-service contracts in the status quo-the depoliticization, the democracy deficit, the commodification of human beingswarrant additional avenues for judicial review. We explore this tension further in Part IV.A, infra.

167. Professor Aman has elsewhere suggested that "[ $t]$ he basic decision to outsource a governmental program is, in and of itself, a significant one and procedural opportunities to question the wisdom of that basic decision should also be provided in a timely way, quite apart from an analysis of the details of the actual outsourcing contract involved." Aman, supra note 130 , at 418 . 
II.B. The commissioner or a body authorized to act on behalf of the agency may commence the outsourcing venture, but they should do so only after notifying the public and inviting comment. ${ }^{168}$

\section{Competitive Bidding}

The decision to outsource is just the first in a series of steps agencies must perform in order to ensure fair and transparent contracting. Under our framework, agencies must employ a consistent, standards-driven approach to awarding human-service contracts. Outsourcing decisions that exceed a certain monetary threshold would be subject to a competitive bidding process. ${ }^{69}$ And within any given regulatory field, caps would be imposed on the extent to which a single firm can acquire market share. Our framework would disallow private monopolies operating in the public sphere.

Although competitive bidding obviously involves cost considerations, the competition we seek to engender is broader and more robust. Firms vying for market share in the private prison industry, for instance, could draw attention not only to their low-cost services but also to their success rate in reducing recidivism. Firms proposing public-private infrastructure for welfare administration could highlight their superior track record in customer service. And because, in addition to competitive bidding, we also propose heightened public participation in the contracting process, ${ }^{170}$ public stakeholders would have an opportunity to help contracting agencies determine which criteria should be treated as dispositive for any given outsourcing venture.

Current law provides for some accountability in contracting. At the federal level, for instance, the Office of Federal Procurement Policy ("OFPP"), housed within the OMB, issues policy guidelines and memoranda "to provide overall direction for government-wide procurement policies,

168. Indiana's welfare privatization project, discussed in supra Part II.B.5, provides a helpful illustration of how not to undertake an outsourcing project. In particular, Professor Aman notes:

The question of whether to outsource [welfare] modernizing tasks to a private provider was never aired publicly. Whether new technologies could, in effect, be insourced to the government rather than contracted out to the private sector was a question that could have benefitted from public discussion before the decision to outsource was made. Nor was the question of whether these types of reforms were worth pursuing, given the complexity and diverse nature of the makeup of the welfare applicant pool.

Aman, supra note 130 , at 400 . Although Indiana's governor did appoint an interagency review committee to study the proposal submitted by IBM, no public hearings were held-and neither actual welfare recipients nor their public-interest advocates were given a meaningful opportunity to weigh in. $I d$.

169. The precise monetary threshold is not important for purposes of this discussion. Our point is simply that some relatively modest dollar figure should separate substantial contracts that warrant heightened scrutiny from minor arrangements that may operate in the background.

170. See infra Part III.A.3. 
regulations and procedures and to promote economy, efficiency, and effectiveness in acquisition processes." ${ }^{171}$ Certain agencies have advertising and competitive bidding requirements included in their enabling acts, while others have promulgated such requirements through regulations. ${ }^{172}$ And Title 41 of the United States Code-concerning public contracts-establishes a broad requirement that executive agencies "in conducting a procurement for property or services shall ... obtain full and open competition through the use of competitive procedures." ${ }^{173}$ Some states impose similar requirements.

But these seemingly robust requirements are swallowed by their numerous exceptions. Take the competitive bidding requirement of Title $4 \mathbf{1}$, for instance. The Code authorizes noncompetitive procedures where, inter alia, the property/services required by an agency are available from only one responsible source; the agency's need for property/services is urgent; or the head of the agency determines that noncompetitive procedures are in the "public interest." ${ }_{74}$ Or take those many federal agencies that lack their own organic procedural statutes: they are governed by the APA, and the APA says nary a word about competitive bidding.

Human-service contracts are precisely the types of agreements for which candor and transparency are most essential. Moreover, these sensitive services require special expertise: before signing a contract, a firm should be required to demonstrate that it has the requisite expertise. Competitive bidding helps to ensure that government's private partners are the best parties for the job.

171. Office of Federal Procurement Policy, OFFICE MGMT. \& BUDGEr, http://www.whitehouse.gov/ omb/procurement_default (last visited Jan. 5, 2017).

172. See, e.g., $4^{2}$ C.F.R. $\$ 4^{1} 4.406$ (2016) (establishing competitive bidding procedures at the Centers for Medicare \& Medicaid Services for certain durable medical equipment acquisitions); 47 C.F.R. $\$ 1.21003$ (2016) (establishing competitive bidding procedures at the Federal Communication Commission for universal service support mechanisms).

173. 41 U.S.C. $\$ 3301$ (a)(1) (2012).

174. Id. $\$ 33^{\circ} 4(\mathrm{a})$; see also 1 PhILIP L. BRUner \& PATrick J. O'Connor, JR., Bruner \& O'CONNOR ON CONSTRUCTION LAW $\$ 2.39$ (2002) ("Public agencies are accorded broad discretion in determining whether competitive bidding is 'feasible' and 'practicable' under the circumstances, and usually have the authority to waive competitive bidding when doing so is clearly in the 'public interest.' At the federal level, this 'catch all' exemption applies generally to any 'public interest,' such as maintenance of a strong industrial base, implementation of international treaties, confidentiality of proprietary information, national security, and standardization and interchangeability of specialized technical equipment." (footnotes omitted)); 64 AM.JUR. 2d PUBLIC WORKS AND CONTRACTS $\$ 32$ (2016) (“[C]ontracts for services, particularly for professional services and other services requiring special training and skill, are generally not contemplated by provisions requiring public contracts for work to be let upon competitive bidding."); Moye, supra note 49 , at 307-og (recounting President Barack Obama's criticisms of increasing federal reliance on sole-source contracts and outsourcing). 


\section{Notice and Comment}

Once an agency has decided to outsource and has at least preliminarily selected a private partner, but before any final agreements are reduced to writing, stakeholders and members of the public should have an opportunity to weigh in once more. Generally speaking, and to the extent feasible, our framework would hold human-service contracts to the same procedural requirements as notice-and-comment rulemaking: that is to say, the content of these contracts (or at least the core provisions) ${ }^{175}$ would be available for public review at individual agency websites or, perhaps, a general internet clearinghouse. ${ }^{17^{6}}$ Agencies would be obligated to solicit, consider, and respond to public input.

In this way, the democracy deficit that inheres in shadowy public-private partnerships would be cured or at least offset, ${ }^{177}$ and agencies that are so often focused on the financial bottom line would be required to consider and engage with the broader array of factors that inform a human-service contract-the same broader array of factors that we contemplate figuring into the competitive bidding process more prominently and explicitly.

A notice-and-comment requirement admittedly would slow the process of contracting in at least some circumstances, but notice-and-comment is hardly a high hurdle for agencies to vault: it is "elegantly simple." ${ }^{178}$ Modest procedure would make public-private partnerships more accountable, more democratic-and more likely to accommodate the needs of the ultimate beneficiaries of human-service contracts.

\section{B. TERMS}

\section{Definitions and Standards}

Agencies contract-in large part-to reduce costs. ${ }^{179}$ But what constitutes "cost?" The definition seems critical: if left open to interpretation, contractors

175. We recognize, of course, that confidentiality concerns may weigh against publishing some of the details of ongoing negotiations. For instance, trade secrets and specific price points might be kept private at these early stages of a public-private partnership. Conversely, some subjects absolutely should be raised at the notice-and-comment stage: agencies should be clear, for example, about precisely what is and what is not being outsourced. Will the contractor simply perform a task previously performed by the agency (or another contractor)? Or is the contractor proposing to innovate or fundamentally alter the way a service is delivered?

${ }_{17} 6$. Such a clearinghouse could provide essential information about human-service contracts across multiple agencies in a convenient, digestible format-akin to Regulations.gov.

177. "A democracy deficit... occurs when public functions are carried out by private actors to the extent that requirements of transparency and public participation-the keystones of administrative democracy-are reduced or set aside." Aman, supra note $5^{2}$, at 87 .

178. Aman, supra note 7, at 417 .

179. "Cost considerations are not limited solely to costs incurred by the regulated. Government costs also have risen, and agency budgets have declined, making new, cost-effective ways to achieve public interest ends increasingly important." Id. at $4^{13}$. 
may be free to construe "cost" in strictly economic terms and to roll back services in an effort to shore up the bottom line. Of course, nothing prevents agencies from imposing a more complete understanding of "cost" through their contracts. But agencies themselves may be susceptible to the prevailing narrative of economic austerity. We cannot count on courts to intervene and reorder the agencies' priorities: as Skidmore, ${ }^{180}$ Chevron, ${ }^{1{ }^{18}}$ and progeny teach, courts are hesitant to interject their own judgment when agencies reasonably interpret ambiguous language in the statutes they are charged with administering. ${ }^{182}$

So if we want human-service contractors to adopt a multifaceted definition of "cost" and to think beyond strict budgetary considerations, it is incumbent upon Congress and state legislatures to make those other values explicit. Which commitments must agencies require of their private partners? And which benchmarks must those partners achieve in order to remain in compliance?

When the DoD outsources under current law, it is required to consider several factors in addition to cost-including quality, reliability, and timeliness. ${ }^{183}$ These terms are not defined in Title 10 , and one could imagine

180. Skidmore v. Swift \& Co., 323 U.S. 134, 140 (1944) ("We consider that the rulings, interpretations and opinions of the Administrator under this Act, while not controlling upon the courts by reason of their authority, do constitute a body of experience and informed judgment to which courts and litigants may properly resort for guidance. The weight of such a judgment in a particular case will depend upon the thoroughness evident in its consideration, the validity of its reasoning, its consistency with earlier and later pronouncements, and all those factors which give it power to persuade, if lacking power to control.").

181. Chevron U.S.A. Inc. v. Nat. Res. Def. Council, Inc., 467 U.S. $837,84^{2-43}$ (1984) ("When a court reviews an agency's construction of the statute which it administers, it is confronted with two questions. First, always, is the question whether Congress has directly spoken to the precise question at issue. If the intent of Congress is clear, that is the end of the matter; for the court, as well as the agency, must give effect to the unambiguously expressed intent of Congress. If, however, the court determines Congress has not directly addressed the precise question at issue, the court does not simply impose its own construction on the statute, as would be necessary in the absence of an administrative interpretation. Rather, if the statute is silent or ambiguous with respect to the specific issue, the question for the court is whether the agency's answer is based on a permissible construction of the statute.").

182. See City of Arlington v. FCC, 133 S. Ct. 1863, 1868 (2013) ("Chevron ... provides a stable background rule against which Congress can legislate: Statutory ambiguities will be resolved, within the bounds of reasonable interpretation, not by the courts but by the administering agency. Congress knows to speak in plain terms when it wishes to circumscribe, and in capacious terms when it wishes to enlarge, agency discretion." (citation omitted)); United States v. Mead Corp., 533 U.S. $218,226-27$ (2001) ("[A]dministrative implementation of a particular statutory provision qualifies for Chevron deference when it appears that Congress delegated authority to the agency generally to make rules carrying the force of law, and that the agency interpretation claiming deference was promulgated in the exercise of that authority."); see also Bernard W. Bell, The Model APA and the Scope of Judicial Review: Importing Chevron into State Administrative Law, 20 WIDENER L.J. 801, 801 (2011) (recognizing that, while state courts have not rushed to incorporate Chevron deference into their own agency review doctrines, Chevron has influenced some state courts, and "several [of these] courts apply strikingly similar standards").

183. 10 U.S.C. $\$ 2461$ (a) (1)(D) (2012). 
a court granting substantial deference to an agency's interpretation of "quality," but the terms represent at least a congressional effort to prevent the DoD from narrowly focusing on the bottom line. Not so with many other federal and state agencies, where outsourcing criteria are nonspecific or wholly reserved to agency discretion.

Our statutory framework would require agencies to provide clear definitions in each human-service contract, giving precise content to ambiguous terms such as "cost." And because of the notice-and-comment procedures we would require at both the launch of an outsourcing venture and immediately before a final agreement is integrated, those definitions would be properly subject to public scrutiny.

\section{Liability}

As discussed in Part II.B.1, constitutional law offers little practical relief for the victims of torts committed by agency delegates. There is no Bivens remedy as against federal contractors, ${ }^{184}$ and state contractors are protected by strict mens rea standards for many constitutional claims ${ }^{18_{5}}$ and a generally recognized extension of Monell's bar on respondeat superior liability for private, for-profit organizations.

Meanwhile, welfare recipients rely on private bureaus to approve and disburse their benefits; inmates depend on commercial-sector security teams to protect them from violence; children attend charter schools, private police and fire departments provide essential services, ${ }^{186}$ and cities spin off utilities they formerly owned and operated. In the morass of public-private partnerships and delegations, mistakes are inevitably made-and the victims of these mistakes should have some means of redress.

Absent movement from the courts on, for instance, the Monell question, contracts-constrained and governed by the statutory framework that we are proposing-could help to ensure that private service providers, like the defendant medical contractor in Shields $v$. Illinois Department of Corrections, ${ }^{187}$

184. See supra note 75 .

185. It is difficult, for example, for a private prisoner to assert and prove that he is the victim of deliberately indifferent acts of cruelty. Deliberate indifference is not an impossible threshold to overcome, but it is an onerous one.

186. See generally THE LAW ENF'T-PRIVATE Sec. Consortium, U.S. DeP'T OF JUSTICE: OfFice OF Cmty. OrIented Policing Servis., Operation Partnership: Trends and Practices In LaW Enforcement and PrIVATe SeCurity Collaborations (2009), http://www.ilj.org/publications/ docs/Operation_Partnership_Private_Security.pdf; Radley Balko, Massachusetts SWAT Teams Claim They're Private Comporations, Immune from Open Records Laws, WASH. POST (June 26, 2014), http:// www.washingtonpost.com/news/the-watch/wp/2014/o6/26/massachusetts-swat-teams-claim-theyreprivate-corporations-immune-from-open-records-laws; William Glaberson, Experiment in Private Fire Protection Fails for a Westchester Village, N.Y. TIMES (Mar. 13, 1998), http://www.nytimes.com/1998/o3/ 13/nyregion/experiment-in-private-fire-protection-fails-for-a-westchester-village.html.

187. Shields v. Ill. Dep't of Corr., 746 F.3d 782 (7th Cir. 2014 ); see also supra notes $69-79$ and accompanying text. 
are exposed to liability when their employees violate the civil rights of third parties. Under our approach, private prisons, welfare bureaus, and other classes of contractors would answer for the constitutional torts of their employees, regardless of whether the organizations themselves maintain unconstitutional policies or customs. Moreover, they would answer for acts of gross negligence, in the same manner that private companies answer for their employees' torts at common law. ${ }^{188}$ Respondeat superior has every bit as much relevance in the context of human-service contracting as it does in ordinary business dealings, and arguably more given the gravity of the interests at stake: if a customer can recover against a business for the fraudulent acts of its employees or for injuries sustained from a slip-and-fall or a malfunctioning product, then vulnerable prisoners injured while incarcerated and welfare recipients whose benefits are unjustifiably terminated should certainly have a reliable avenue for judicial relief.

\section{Duration, Revision, and Novation}

Imposing durational limits on contracts may in some instances encourage contractors to respect human rights-if not out of moral obligation, then out of sound business sense. In a case concerning the privatization of prisons in Tennessee, the Supreme Court of the United States addressed the limited duration of Tennessee's prison contracts and the power of that state to cancel at any time after the first year of operation. Writing for the Court, Justice Breyer observed:

Competitive pressures mean not only that a firm whose guards are too aggressive will face damages that raise costs, thereby threatening its replacement, but also that a firm whose guards are too timid will face threats of replacement by other firms with records that demonstrate their ability to do both a safer and a more effective job. ${ }^{189}$

Under our statutory framework, human-service contracts would either: (1) include default sunset dates (with options to renew based on performance); or (2) authorize contracting agencies to reevaluate the efficacy of long-term contracts after a certain, modest period of time has elapsed. Contracts bound by our framework would also include terms that authorize early termination or modification in case of substantial breach or a material change in circumstances. So long as private contractors are aware of these

188. Certainly, the victims of contractor torts may have a remedy under some state tort regimes in the status quo. However, these regimes vary wildly in, for instance, the statutes of limitation they impose, their caps on damages, and whether public-private partmerships are shielded under commonlaw principles of sovereign immunity. We envision a more uniform-and generous-regime to ensure that tort victims have ample opportunity for recovery and are protected from "the vagaries of the laws of the several States." Carlson v. Green, 446 U.S. 14, 23 (1980).

189. Richardson v. McKnight, 521 U.S. 399, 409 (1997). 
terms and restrictions up front, there is no need for concern about unconstitutional contract impairment: private parties can account for the risk of change through arms-length bargaining, and agencies will be protected in the event that they exercise their statutorily guaranteed rights to terminate or modify. ${ }^{190}$

\section{Freedom of Information}

The Freedom of Information Act ("FOIA"), ${ }^{191}$ along with its many statelaw counterparts, ${ }^{192}$ requires agencies to publish substantive/procedural rules and organizational information; release adjudicative opinions, policy statements, administrative materials, and other documents for public inspection; and make "reasonable efforts" to search for requested records and deliver them in any "readily reproducible" form or format requested. FOIA is lengthy, and it features a variety of procedural requirements, governing everything from fee schedules 193 to tracking and information-management systems $^{194}$ to judicial enforcement where agencies fail to comply with their obligations. ${ }^{195}$

FOLA also expressly defines the class of agencies to which it applies. FOIA covers "any executive department, military department, Government corporation, Government controlled corporation, or other establishment in the executive branch of the Government ... or any independent regulatory agency." $19^{6}$ From that definition, it appears that FOIA does not apply to private-sector firms carrying out governmental responsibilities. In fact, the case law in this area is somewhat more nuanced than the statutory language

19o. The proposed EU Model Rules include similar provisions, authorizing the EU authority to override contract terms in good faith through its exercise of public-authority powers and allowing for termination by either party in situations involving: (1) material changes of circumstances; (2) risk of "grave harm to the common good"; (3) nonperformance; (4) procedural violations that harm a third party; or (5) contractual illegality. See AUBY ET AL., supra note 162 , at $166,169-71$.

191. Freedom of Information Act, 5 U.S.C. $\$ 55^{2}$ (2012) [hereinafter "FOIA"].

192. State Freedom of Information Laws, NAT'L FREEDOM INFO. COALITION, http://www.nfoic.org/ state-freedom-of-information-laws (last visited Jan. 5, 2017); see also generally Charles N. Davis et al., Sunshine Laws and Judicial Discretion: A Proposal for Reform of State Sunshine Law Enforcement Provisions, 28 URB. LAW. 41 (1996); Aimee Edmondson \& Charles N. Davis, "Prisoners" of Private Industry: Economic Development and State Sunshine Laws, 16 COMM. L. \& POL'Y 317 (201 1); Michael W. Field, Rhode Island's Access to Public Records Act: An Application Gone Awry, 8 RoGER WLLIAMS U. L. REV. 293 (2003); Alyssa Harmon, Note, Illinois's Freedom of Information Act: More Access or More Hurdles?, 33 N. ILI. U. L. REV. 601 (2013); Cassandra B. Roeder, Note, Transparency Trumps Technology: Reconciling Open Meeting Laws with Modern Technology, 55 WM. \& MARY L. REV. 2287 (2014). For brevity in this section, we focus primarily on the law of FOIA proper, but our analysis could easily extend to many similar-and similarly construed-state laws.

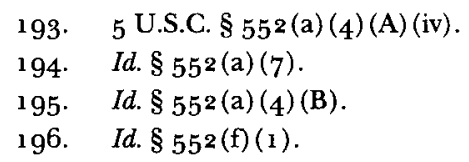


would suggest, ${ }^{197}$ but many private contractors have successfully avoided the spotlight of FOIA. The problem is amplified in the private-prison sector, where, "[d] espite consistent attempts to apply FOIA to the industry . . . tens of thousands of individuals incarcerated by the federal government are in facilities beyond the reach of this form of oversight." 198

The documents and memoranda that agencies generate in the process of receiving bids for private contracts and structuring deals could fall within FOlA's domain-but such information could also be characterized as exempt from disclosure under section $55^{2}$ (b) (4). ${ }^{199}$

Transparency and accountability rank high on any list of potential concerns relating to privatization, and administrative-law scholars have criticized the transparency deficit as agencies increasingly rely on private partners. ${ }^{200}$ Professors Cate, Fields, and McBain noted that FOIA has at least

197. Courts have in some cases extended FOLA to private corporations acting under governmental control. See Rocap v. Indiek, 539 F.2d 174, 176 (D.C. Cir. 1976) (treating the Federal Home Loan Mortgage Corporation as an agency under FOLA); cf. Pub. Citizen Health Research Grp. v. Dep't of Health, Educ. \& Welfare, 668 F.2d 537, 538 (D.C. Cir. 1981) (finding that a contractor foundation was not an agency under FOIA). In other cases, courts have extended FOIA to private corporations that assume functional equivalence with federal agencies. See Soucie v. David, 448 F.2d 1067, 1071 (D.C. Cir. 1971) (treating the Office of Science and Technology as an agency under FOIA); $c f$. Wash. Research Project, Inc. v. Dep't of Health, Educ. \& Welfare, $5^{\circ} 4$ F.2d 238, 246 (D.C. Cir. 1974) (finding that advisory committees serving the NIMH were not agencies under FOIA). In cases in which an entity is not deemed to be an agency for FOIA purposes, its records may still be subject to the law if they constitute "agency records," a term that appears in, but is not specifically defined by, FOIA. However, the agency-records exception is a nonstarter for many private entities: "the Supreme Court has established that an agency must have custody and control of records to create a sufficient nexus for a finding of agency record status." Nicole B. Cásarez, Furthering the Accountability Principle in Privatized Federal Corrections: The Need for Access to Private Prison Records, 28 U. MICH. J.L. REFORM 249, 280 (1995). Thus, internal records stored on secure servers at, for instance, CCA or GEO Group detention centers are unlikely to fall within the four corners of FOIA.

198. Mike Tartaglia, Note, Private Prisons, Private Records, 94 B.U. L. REV. 1689, 1738-39 (2014).

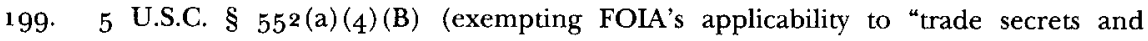
commercial or financial information obtained from a person and privileged or confidential"). But cf. Martha Minow, Outsourcing Power: How Privatizing Military Efforts Challenges Accountability, Professionalism, and Democracy, 46 B.C. L. REV. 989, 999 (2005) ("Private companies are free from the disclosure obligations placed on the government by the FOIA, the federal law intended to make democracy work by ensuring access to all of the government's information compatible with security. There is some authority that private companies enjoy the ability to enjoin the government from disclosing information they have shared with the government in the course of doing business together." (footnote omitted)).

200. Jack M. Beermann, Privatization and Political Accountability, 28 FORDHAM URB. L.J. 15 \% 1554 (2001) ("Privatization threatens to undermine the accountability provided by the APA and FOIA in several ways, some obvious and some not so obvious. Most obviously, insofar as a private entity is not subject to the APA or FOIA, the accountability advantages of those statutes are lost. ... Private companies developing rules of thumb for dealing with claims or other matters affecting the public might not have to publish those rules under the APA, and the lack of public access to their records and meetings might make it difficult for the public to even know of such rules' existence."). Professor Fenster pointed to a particular irony at the intersection of privatization and freedom of 
three core functions: (1) it empowers the public to serve as a "watchdog" over governmental officials; (2) it assures public access to agency information concerning public policy; and (3) it prevents agencies from creating or enforcing laws in secret. ${ }^{201}$ Each of these valuable goals is undercut when agencies delegate governmental power to entities excluded from FOIA's coverage.

In an influential 1999 article, Professor Craig Feiser asserted that "in an age of privatization of governmental services in the name of efficiency, [FOIA] needs to be adapted to ensure that its original purpose remains sound." ${ }_{202}$ Feiser rejected narrow interpretations/extensions of the statute, and argued instead that "if the records pertain to the government, they are of interest to the public and should be opened for scrutiny," regardless of whether the government controls those records in a technical sense and regardless of whether the private entity that holds them is acting as the functional equivalent of the government. ${ }^{203}$

Professor Jack Beermann agreed that it is possible to maintain accountability and transparency in a world of government-by-contract:

Perhaps courts should deem any rules ... developed by a private contractor to be rules of the agency and apply the APA's publication requirement. Agencies also should provide clear instructions to private providers of government benefits, and should not allow the private companies to make discretionary decisions that, if made by an agency, would be subject to the APA and FOLA's accountability enhancing procedures. ${ }^{204}$

Rather than relying on courts to construe FOIA and its state equivalents broadly, our framework would amend these laws to treat human-service contractors like official agencies for freedom-of-information purposes. If there is legitimate concern that critical business data could be exposed, legislatures could expand their trade-secrets exemptions to ensure that these exemptions cover the internal financial reports and other confidential documents pertaining to the per se business operations of human-service contractors. But to the extent that these contractors seek to conceal records of genuine interest to the public-concerning health and safety, systemic IT problems, or complaints and enforcement actions by third-party

information: "[F]ederal agencies have begun to contract out their own responses to FOIA requests-leading inevitably to the issue of whether records produced by the private firms engaged in reviewing FOIA requests would themselves be subject to FOLA." Mark Fenster, The Opacity of Transparency, 91 IOWA L. REV. 885, 919 (2006) (emphasis added) (foomote omitted).

201. Fred H. Cate et al., The Right to Privacy and the Public's Right to Know: The "Central Purpose" of the Freedom of Information Act, 46 ADMIN. L. REV. 41, 42-43 (1994).

202. Craig D. Feiser, Privatization and the Freedom of Information Act: An Analysis of Public Access to Private Entities Under Federal Law, 52 FED. COMM. L.J. 21,62 (1999).

203. Id.

204. Beermann, supra note 200, at 1555 (footnote omitted). 
beneficiaries-the trade-secrets exemptions should provide no cover, and freedom-of-information statutes should guarantee more open government.

\section{ENFORCEMENT}

It seems almost tautological to assert that effective contracts require effective enforcement mechanisms. Parties covenant to perform certain tasks according to delineated standards; where parties fail to perform, or where their efforts are subpar, they face legal consequences.

But because the APA and many state procedural laws impose no uniform requirements for the kinds of enforcement mechanisms agencies must include in their contracts, those decisions are essentially left to the agencies themselves, influenced as they are by the narrative of austerity that informs so much of contemporary realpolitik. ${ }^{205}$

For purposes of our statutory framework, we have conceived of three possibilities to ensure consistent and robust enforcement. First, as suggested above, establishing contracts of limited duration (with the opportunity for renewal if outcomes are favorable) may encourage private-party compliance. This approach, by itself, is probably insufficient, but it does have the decided benefit of coaxing self-enforcement: firms want to retain their lucrative government contracts, and so they have an economic motivation to comply. ${ }^{206}$

Second, third-party auditors may be appropriate in a variety of circumstances. For example, public-policy activities done by the Government Accountability Office ("GAO") "might be duplicated by private-group certification of the private delivery of social services." ${ }^{207}$ Theoretically, these auditors-disinterested parties with a public-interest mandate-could evaluate both the efficacy of outsourcing in general and the quality of particular services delivered (i.e., is the contractor performing up to snuff?). Red flags could be raised as needed before the appropriate agency officials, and, potentially - depending on the gravity of the breach-before the public at large. ${ }^{208}$

Third, we think it may be helpful to characterize the ultimate recipients of public-private human services as third-party contract beneficiaries of sorts. The term "beneficiaries" may seem a bit peculiar, given that many of those on

205. Mary E. Harney, The Quiet Revolution: Downsizing, Outsourcing, and Best Value, $158 \mathrm{MIL}$.

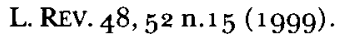

206. Whereas if the duration of a contract is indefinite, a firm with a reasonable risk appetite might "roll the dice" on some minor breaches, figuring either that (1) the agency will not notice or (2) the agency is unlikely to trouble itself with the hassle and litigation surrounding contract termination unless the breach is extraordinary.

207. AMAN, supra note 5 , at 151 .

208. While minor discrepancies could probably be resolved in-house, the public has the right and the responsibility to know when human rights are harmed by public agencies or their private agents. See supra Part II.B for a discussion of various human-service contracts and the abuses that have occurred where monitoring has failed or where dignitary expectations were never very clear in the first place. 
the receiving end of human-service contracts are unwilling recipients: federal prisoners and immigration detainees, as well as homeless persons and welfare recipients who are no doubt grateful for the aid they receive but who surely would prefer a more stable, self-sustaining situation.

But our point is that these vulnerable parties are the very persons whose rights are jeopardized in the status quo and who would benefit most directly from a reboot of administrative procedure. Regardless of the circumstances that caused them to rely on government or government-sponsored services, here they are-and if we statutorily empower them to fight back when contractors breach, they can help enforce public-private agreements broadly even as they vindicate their rights individually. ${ }^{209}$

We suspect that contractors would fall quickly in line if they knew that not only government officials but also the prisoner in need of surgery or the single parent in need of SNAP benefits could take them to task for their failure to comply with their contract's letter and/or spirit.

\section{Countervailing Considerations}

\section{A. OPENING THE FLOODGATES?}

The framework we have just laid out would, we think, fill hazardous gaps in the APA and its state equivalents, preserving agency flexibility in this complex, emerging global era, while simultaneously ensuring that basic human rights and democratic principles are not undercut in the name of efficiency. We think our approach would work well with the types of humanservice contracts we described in Part II, and quite possibly with other such contracts that we have not explicitly addressed.

But we recognize that our proposal, like any effort to address a complex problem, is an imperfect one. Perhaps the most obvious concern relates to our recommendations for expanded respondeat superior liability, as stated in Part III.B.2, and third-party contract enforcement, as stated in Part III.C. We anticipate a counterargument: isn't it unwise to burden the courts, overwhelmed as their dockets are, with a new class of litigants emboldened by

209. In his article on Indiana's failed welfare privatization experiment, Professor Aman proposed just such a third-party enforcement scheme, suggesting that "[c]ontracts between private companies and states could recognize welfare recipients as third-party beneficiaries to the contract to allow recipients legal redress when private contractors violate the terms of the contract in a way that results in the unlawful deprivation of benefits." Aman, supra note 1.30, at 419-20. Professor Aman noted the irony of a politically hypersensitive, unprecedented arrangement the enforcement of which the state alone could pursue: "Given the diverse interests at stake and the state's desire to have its contract work as efficiently as possible, it might not be as willing to challenge the contractor as those whose benefits are very much on the line." Id. at 420 . Our proposal here extends Professor Aman's earlier recommendation: any recipient of a humanservice contract benefit should have: (1) standing to file an administrative grievance or, if necessary, a lawsuit; (2) a statutorily authorized cause of action for breach; and (3) clearly defined contract remedies, perhaps including specific performance for those contracts that cannot be easily unwound or re-delegated. 
fresh statutory causes of action? And isn't it particularly unwise to arm prisoners and detainees with such tools, given the inherently litigious position they occupy (i.e., few limits on their time and relatively little to lose)?210

We have two responses to these reasonable concerns. First, if contractors are aware that they can no longer hide behind the guise of privity, immunity, Monell s constraint on respondeat superior, Minneci's limitation on the Bivens remedy, or any of the other mechanisms they presently employ to avoid liability and to dodge their contractual responsibilities, they are likely to be more conscientious with respect to the policies they implement, the employees they hire and train, and the activities they undertake. Simply put: placing liability on the table will ensure that all comers have the correct incentives to perform their jobs with the upmost care-and a statutory regime with clearly defined standards and remedies is far superior to the vagaries of state tort law or whatever inchoate theories litigants are forced to fall back on in the status quo.

Moreover, the type of liability we are describing here is really not so far removed from the common law. Judge Hamilton made this point in Shields, as he challenged the prevailing notion that Monell should protect private corporations from section 1983 actions on the basis of employee conduct:

Perhaps the most important criticism to emerge ... is that Monell failed to grapple with the fact that respondeat superior liability for employers was a settled feature of American law that was familiar to Congress in 1871 , when $\S 1983$ was enacted. Congress therefore enacted $\S 19^{8} 3$ against the backdrop of respondeat superior liability and presumably assumed that courts would apply it in claims against corporations under $\$ 19^{8} 3 \cdot \cdot^{211}$

Private corporations should answer for the conduct and malfeasance of their employees, and agents of the public's business (whether governmental agencies proper or private-sector stand-ins) should answer to the public.

\section{B. EIEVATED COSTS UNDERMTNE EFFECTIVE DELEGATIONS?}

Another counterargument we anticipate: won't the cost of heightened process and procedure (and exposure to putative liability) deter contractors from signing on with government partners in the first instance? And won't such deterrence undermine the flexibility that is so critical to 21 st-century governance (particularly in states with chronic budget shortfalls)?

The costs that our statutory framework would impose might discourage some private actors from signing on to agency contracts, at least on the

210. Indeed, this was the primary argument that prompted Congress to enact the Antiterrorism and Effective Death Penalty Act of 1996 ("AEDPA"), which significantly rolled back the procedural rights and remedies available to federal habeas petitioners. See Antiterrorism and Effective Death Penalty Act of 1996, Pub. L. No. 104-132, 110 Stat. 1214.

211. Shields v. Ill. Dep't of Corr., 746 F.3d 782, 791-92 (7th Cir. 2014). 
margins. But we do not think this argument poses a serious hurdle, for two reasons. First, there is significant money to be made in the public-private industry. Consider private prisons, for instance. In 2010, CCA enjoyed record revenues of $\$ 1.67$ billion, while GEO Group brought in $\$ 1.27$ billion. ${ }^{212}$ The welfare administration industry is lucrative as well. Indiana's current eightyear contract with ACS is worth $\$ 6{ }_{3} 8$ million, ${ }^{213}$ while a contract with Accenture to manage Texas's CHIP program and Medicaid/SNAP call centers was once valued at $\$ 899$ million. ${ }^{214}$ After a series of training and technical "snafus," Texas canceled the contract-\$244 million in.215 Tim Dowd, a market-research executive, estimated that state outsourcing amounted to $\$ 8.8$ billion in 2009 -and that it would rise five percent annually thereafter. ${ }^{26}$ So to whatever extent our proposal might raise costs, the extraordinary financial benefits of dealing with the government will likely remain persuasive for many putative contractors. ${ }^{917}$

Second, to the extent that traditional for-profit entities exit the market in the face of increasing process and costs, nonprofit or public-benefit entities may fill the gaps. If we are genuinely concerned about the preservation of human dignity and individual rights, perhaps this transition would not be such a bad thing. Public-benefit corporations in particular are making waves in statehouses across the nation; ${ }^{218}$ these entities seem ideally situated to carry out the public's business (and prioritize philanthropic values) while still turning a reasonable profit for their shareholders. ${ }^{219}$

2 12 . Justice POLicy InSt, Gaming the System: How the POlitical Strategies of Private PRISON COMPANIES PROMOTE INEFFECTIVE INCARCERATION POLICIES 1-2 (2011), http://www.justice policy.org/uploads/justicepolicy/documents/gaming_the_system_-_executive_summary.pdf.

213. Gold et al., supra note 135 .

214. Aman Batheja, In State Contracting, Failure Is an Option, TEX. TRIB. (Feb. 1, 2015, 6:00 AM), http://www.texastribune.org/2015/02/o1/cost-overruns-and-bungles-state-contracting.

215 . Id.

216. William M. Bulkeley, Glitches Mar Indiana's Effort to Outsource Social Services, WALL STREET J., http://www.wsj.com/articles/SB1 25003802691324435 (last updated Aug. 12, 2009, 12:01 AM).

217. For that matter, there is an argument that some added costs to internalize the effectiveness and fairness of privatization might strengthen public-private partnerships in the long haul, ensuring their viability (which in turn redounds to the benefit of the contractors).

21 8. See, e.g., Daniel Fisher, Delaware 'Public Benefit Conporation' Lets Directors Serve Three Masters Instead of One, ForBes (July 16, 2013, 2:06 PM), http://www.forbes.com/sites/danielfisher/2013/ 07/16/delaware-public-benefit-corporation-lets-directors-serve-three-masters-instead-of-one; Jack Markell, A New Kind of Conporation to Hamess the Power of Private Enterprise for Public Benefit, HUFFINGTON POST: BLOG, http://www.huffingtonpost.com/gov-jack-markell/public-benefit-corporation_b_36357 $5^{2 . h t m l ~(l a s t ~ u p d a t e d ~ S e p t . ~ 21, ~ 2013) ; ~ s e e ~ a l s o ~ S t a t e ~ b y ~ S t a t e ~ S t a t u s ~ o f ~ L e g i s l a t i o n, ~ B E N E F I T ~ C O R P ., ~}$ http:/ /benefitcorp.net/policymakers/state-by-state-status (last visited Jan. 5, 2017).

219. Public-benefit corporations are creatures of recent legislation, and not much scholarly attention has been paid to them to date. For a helpful overview of these hybrid entities, see generally Briana Cummings, Note, Benefit Corporations: How To Enforce a Mandate To Promote the Public Interest, 112 COLUM. L. REV. 578 (2012). Cummings describes public-benefit corporations as entities with "double bottom lines":

[D]ouble bottom line corporations neither treat social responsibility as incidental 


\section{DUPLICATIVE LEGISLATION?}

As discussed throughout this Article, our statutory framework-though it was inspired by deficits in the APA as applied in today's socioeconomic and political climate-is designed to function at state and federal levels alike. State outsourcing is big business, and some of the human-service contracts that most concern us (principally private prisons, welfare administration, and provision for the homeless) are largely the province of state rather than federal law.

But one might argue that not all state-level administrative procedure laws are as impoverished as the federal APA with respect to contracting and publicprivate partnerships. In Massachusetts, for instance, a general statute authorizing privatization employs "multiple rationales for privatizing, and seeks to elicit the reasons and goals of the privatization proposal under consideration prior to authorization." ${ }^{20}$ The statute candidly recognizes that "using private contractors to provide public services formerly provided by state employees does not always promote the public interest."

Ohio's prison-privatization statute increases accountability and opportunities for public input by providing that contracts "shall be for an initial term [of not more than two years], with an option to renew for additional periods of two years." ${ }^{222}$ Tennessee requires private prisons to "agree that the state may cancel the contract at any time after the first year of operation, without penalty to the state, upon giving ninety (9o) days' written notice." ${ }^{223}$ And the District of Columbia monitors outsourcing through its Office of Contracting and Procurement ("OCP").224

But other states maintain a more permissive view of contracting. Colorado provides a helpful illustration: its stated policy, adopted in response to a constitutional amendment that constrained government activities, is "to

to profit-making ... nor see profit-making as incidental to the pursuit of social welfare objectives .... Instead they seek to serve two "co-equal" masters (two bottom lines) at once-to "expressly measure[] [their] success both in terms of [their] financial performance ... and [their] success in advancing a social mission."

$I d$. at $5^{81-82}$ (footnotes omitted) (third omission in original) (alterations in internal quote found in original).

220. Aman, supra note 16 , at 272 (emphasis added).

221. MASS. GEN. LAWS ch. 7, § 52 (2014).

222. OHIO REV. CODE ANN. § 9.o6(A) (1) (West 2016).

223. TENN. CODE. ANN. \$41-24-104(a) (4) (2014).

224. The Office of Contracting and Procurement ("OCP") coordinates procurement activities within the District and reviews, monitors, and audits these activities. D.C. CODE $\S 2-35^{2.04}$ (2001). Contractors must meet a set of baseline standards, including satisfactory records of performance/integrity and adequate financial resources to perform under the proposed contract. Id. $\$ 2-353.01$. Competitive bidding is governed by rules customized to the type of contact under consideration: "emergency procurements" and "human care procurements" are subject to special rules and guidelines. Id. $\$ \S 2-354.05$ to 2-354.o6. 
encourage the use of private contractors for personal services to achieve increased efficiency in the delivery of government services." 225

Similarly, West Virginia and Montana both have prison-privatization statutes expressing a legislative embrace of outsourcing. In West Virginia, the legislature has found that: (1) "adequate and modern prison facilities are essential to the safety and welfare of the people of this state and other states"; (2) "contracting for portions of governmental services is a viable alternative for this state and its political subdivisions"; and (3) "allowing for the establishment of private prison facilities is an economic development opportunity for local communities and will augment the general revenue fund." ${ }_{226}$ As for Montana, " $[t]$ he state recognizes that there may be benefits to confining convicted persons in private correctional facilities operated consistently with public policy. ${ }^{227}$

Idaho has a statute authorizing private security forces to secure the capitol building and the state supreme court. ${ }^{228}$ Oklahoma allows private prison contracts to run for $5^{\circ}$ years at a time, albeit subject to annual appropriations.229 In California, state and municipal authorities are constitutionally entitled "to contract with qualified private entities for architectural and engineering services for all public works of improvement," with such entitlement extending "to all phases of project development including permitting and environmental studies, rights-of-way services, design phase services and construction phase services." ${ }_{230}$ And in Oregon, where forestry is the lifeblood of the local economy, ${ }^{231}$ the State Forestry Department is statutorily required to " $[\mathrm{e}]$ ncourage the use of private contractors, consultants, [and] forestry extension programs." ${ }_{232}$

These statutes (and others like them) lead us to three conclusions: first, that contracting at both state and federal levels is pervasive in contemporary governance; second, that jurisdictions vary wildly in the types of contracts they contemplate and the limitations they impose; and third, that a uniform approach to human-service contracting in particular has not been adopted (or even, so far as we are aware, seriously proposed). Some states are certainly

\footnotetext{
225. COLO. REV. STAT. $\$ 24-50-501$ (2016).

226. W. VA. CODE ANN. $\$ 25^{-5}-2$ (2013).

227. MONT. CODE ANN. $\$ 53-30-601$ (2015).

228. IDAHO CODE $\$ 67-1605$ (2014).

229. OKLA. STAT. tit. 19, $\S 744$ (2011). Perhaps more concerning, “[a] private contractor, in implementing a contract pursuant to the provisions of this section, shall not be bound by state laws or other legislative enactments which govern the appointment, qualifications, duties, salaries or benefits of jailers or other employees of the jail facilities." Id. $\$ 744 \mathrm{~J}$.
}

23o. CAL. CONST. art XXII, $\$ 1$.

231. Keeping Oregon Forests Working, OREGONFORESTS.ORG, http://oregonforests.org/ content/forest-sector-economy (last visited Jan. 5, 2017) ("The forest sector contributes: \$12.7 billion to Oregon's economy each year. More than 58,000 living-wage jobs. $6.8 \%$ of Oregon's total industrial output. Millions of dollars of tourism annually.").

232. OR. REV. STAT. $\$ 5^{26.710(5)(2015) .}$ 
ahead of the game, but others are lagging behind. At bottom, we suggest nothing more than a simple framework to help bring order to the legislative morass and to encourage effective reform.

\section{THE FUTURE OF ADMINISTRATIVE LAW}

This Article has made bold recommendations for a new legal regime to govern the public-private partnerships that are ubiquitous in contemporary agency practice. We are calling for a 21 st-century reboot of the APA and of state administrative-procedure laws; more fundamentally, we are calling for the active preservation of human rights through administrative law.

The arc we have constructed-from general-service contracts to humanservice contracts and contracts potentially beyond the scope of permissible delegation-may help scholars and policymakers begin thinking more intentionally about the implications of contemporary delegation. The examples we supply in Part II.B represent categories of contracts in which human services are significantly implicated, such as those involving prisons and detention centers, welfare programs, or police and emergency-response entities.

But the tapestry of public-private partnerships is intricate, interwoven with countless iterations of hybrid relationships. Within the framework we have proposed, there is ample space for additional scholarship and reflection.

Charter schools are another case in point. There is considerable legal debate over whether and to what extent these entities are "public" at all.233 They are funded by the state but increasingly independent and (arguably to their detriment) free of accountability and oversight. And while they provide an essential service traditionally reserved to the state, they do not consistently guarantee the constitutional rights afforded to public school students. In the Ninth Circuit, for instance, only one of the seven states with legislation authorizing charter schools guarantees that all federal rights apply to such schools. ${ }^{234}$

Yet schools implicate a host of human-rights concerns. They are places of compulsory learning, where students' vocational prospects and life chances

233. Compare Preston C. Green III et al, Charter Schools, Students of Color and the State Action Doctrine: Are the Rights of Students of Color Sufficiently Protected?, 18 WASH. \& LEE J. C.R. \& SOC. JUST. 253, 256 (2012) ('Because state authorizing statutes consistently define charter schools as 'public schools,' it would appear that charter school students are entitled to constitutional protections." (foomotes omitted)), with Caviness v. Horizon Cmty. Learning Ctr., Inc., 59o F.3d 806, 818 (9th Cir. 2010) (finding allegations "insufficient to raise a reasonable inference that [charter school] was a state actor and thus acted under color of state law in taking the alleged [termination] actions").

234. "With the exception of Oregon, state legislatures [in Ninth Circuit jurisdictions] do not compel charter schools to follow constitutional guidelines with respect to due process. California and Idaho merely require potential charter school operators to disclose their disciplinary policies in their initial charter application. Alaska, Arizona, Hawaii, and Nevada do not even demand that charter schools disclose their disciplinary policies at the time of application." Green et al., supra note 233 , at 272 (footnotes omitted). 
are largely defined by the quality of instruction and care they receive. Schools provide food and emergency medical care for children. They provide security-at least in theory-from outside threats, and protectionoptimistically-from abusive behavior in the halls and the schoolyard. And schools engage in discipline and punishment as well, albeit without the panoply of procedural protections available in the criminal-justice system. ${ }^{235}$ The principles we have articulated and the model statutory provisions we have recommended could liven the debate concerning the delegation from state departments of education to charter schools: like contracts for prisons or welfare programs, contracts for schools should arguably be open to public inspection and participation, with mandatory terms, built-in oversight mechanisms, and enforcement by third-party beneficiaries (e.g., students, parents, and teachers).

There is also space for reformation of governance-by-contract in contemporary environmental initiatives. Urban communities are grappling with the problem of brownfields (i.e., abandoned or underused real-property sites, the redevelopment of which may be complicated by the presence of contaminants). ${ }^{236}$ The EPA estimates that there may be as many as $45^{\circ}$, ooo brownfields throughout the country, while some estimates suggest that there are as many as five million acres of abandoned industrial sites nationwide. ${ }^{237}$ The problem is not merely aesthetic: brownfields raise urgent questions about health, safety, and vitality in urban centers.

Yet municipalities, particularly those with large abandoned sites, often lack the funds to clean and redevelop brownfields on their own. As one author suggested, " $[\mathrm{t}]$ he best way to facilitate brownfields redevelopment may be for public and private entities to work together through public-private partnerships." ${ }^{28} 8$ But public-private redevelopment of brownfields could be a tragically missed opportunity if the private financiers and developers are not bound to contract terms that advance the public interest. The most lucrative projects may not necessarily be the most edifying. Contracts that invite public participation may lead to better outcomes, such as more green spaces, more affordable housing, and mixed-use properties that meet the practical needs of residents.

235. Ingraham ex rel. Ingraham v. Wright, $43^{\circ}$ U.S. $65^{1}, 68_{3}$ (1977); Goss v. Lopez, $4^{1} 9$ U.S. $565,580(1975)$.

236. Scott W. Brunner, Comment, Sharing the Green: Reformatting Wisconsin's Forgotten Green Space Crant with a Public-Private Partnership Design, 95 MARQ. L. REV. 305, 309-10 (201 1 ).

237. Oni N. Harton, Note, Indiana's Browmfields Initiatives: $A$ Vehicle for Pursuing Envinonmental Justice or fust Blowing Smoke? 41 IND. L. REV. 215,219 (2008); see also NAT'L Ass'N. OF CTYS., FEDERAL. FUNDING PROGRAMS FOR BROWNFIELDS AND ABANDONED SITE REDEVELOPMENT: PAST, PRESENT AND FUTURE: A PRIMER FOR COUNTY OFFICIALS 3 (2008), http://www.naco.org/sites/default/files/documents/SLU_

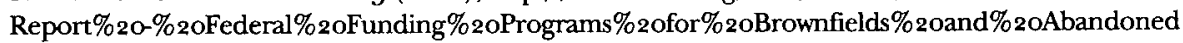
$\%$ zoSite\% zoRedevelopment.pdf.

$23^{8}$. Brunner, supra note $23^{6}$, at 328 . 


\section{CONCLUSION}

"[W] hen government concerns itself with the stability of an industry it is only intelligent realism for it to follow the industrial rather than the political analogue." ${ }_{39}$

These words, penned by James Landis many decades ago, echo and reverberate today, as federal and state agencies continually adapt and reform their modes of governance. Like 2 ist-century firms, with their global supply chains, their diffuse management structures, and their shift from ownership to cooperation, modern agencies rely with ever-increasing urgency on contracts and partnerships to perform a range of services, from those we think of as banal to those that touch and concern the most sensitive aspects of our society.

In the status quo, many agency actions-even those with significant public ramifications-receive little public attention. This is true even at the federal level, where one might reasonably expect a greater degree of interest (given heightened public awareness of prominent federal agencies and the potentially broad impact of their rulemaking). ${ }^{2} 4^{\circ}$ But our assumption is that opening the door to elevated public participation in human-service contract formation would not necessarily burden agencies-because presumptively fair and reasonable terms on the one hand, and public inertia on the other, would likely temper aggressive participation. ${ }^{24}$

239. LANDIS, supra note 4 , at 11-12.

240. A casual review at Regulations.gov of comment periods closing during the month of November 2014 found zero comments submitted with respect to, inter alia, a National Science Foundation inquiry regarding Big Data Regional Innovation Hubs, see Accelerating the Big Data Innovation System, REGULATIONS.GOV, https://www.regulations.gov/document ?D=NSF_FRDOC_ooo1-1370 (last visited Jan. 5, 2017); proposed amendments to exempt certain DOI records from provisions of the Privacy Act, see Privacy Act; Systems of Records: Exemption for the Insider Threat Program, REGULATIONS.GOV, https://www.regulations.gov/ document? D=DOI-2014-0009-0001 (last visited Jan. 5, 2017); and a proposed EPA rule authorizing retroactive approval of hazardous waste initiatives in Arkansas, see Hazardous Waste Management Programs: Arkansas; Final Authorization of State-Initiated Changes and Incorporation by Reference, Proposed Rule, REGULATIONS.GOV, https://www.regulations.gov/ document?D=EPA-Ro6-RCRA-201 2-0793-0002 (last visited Jan. 5, 2017). Of course, the public is not always lackadaisical. A Fish and Wildlife Service proposal to list the African lion as a threatened subspecies generated 384,056 comments as of November 2, 2014, see Endangered and Threatened Wildlife and Plants: 9o-Day Finding on a Petition to List the African Lion Subspecies as Endangered, REGULATIONS.GOV, https://www.regulations.gov/document?D =FWS-R9-ES-2012-0025-0001 (last visited Jan. 5, 2017); and a proposed change to the definition of "waters of the United States" under the Clean Water Act generated 1,128,115 comments, see Clean Water Act; Definitions: Waters of the United States, REGULATIONS.Gov, https://www.regulations.gov/document? D=EPA-HQ-OW-201 1-o88o-ooo 1 (last visited Jan. $5,2016)$.

241. Conversely, if an agency proposes to do something egregious-say, contract away significant rights and liberties or delegate excessive discretion to market actors-the public might well respond, and agencies should be required to pause and reevaluate under such circumstances. 
Ultimately, while our proposal, with its added procedural requirements, would inevitably add some time and cost to delegation, we think the depoliticization of important judgments, the deprivation of democratic process, and the commodification of human beings in the status quo amply justify some additional procedure. This is our vision of administrative law-as more than the sum of its parts; as a vehicle to vindicate individual rights.

What we have proposed in this Article is a simple framework that federal and state governments could weave into their administrative procedure statutes-a series of checks and balances inspired by the core elements of contract (formation, terms, and enforcement). The idea is not to impose a rigid set of requirements on agencies: we understand that jurisdictions (and their constituents) have different priorities, and we suspect that the adoption of a framework like the one we are proposing would look different in different parts of the country. ${ }^{24^{2}}$ We also understand that our framework is just that-a framework. It is not a model statute. It surely has its downsides, and those are worth probing.

But it could also be the beginning of a conversation. What we hope our Article has conveyed, above all, is a sense of urgency for administrative law to address the democracy deficit and the commodification of human beings brought about by increased and relatively unrestrained human-service contracting. Where injured prisoners are left without remedies; ${ }^{243}$ where the welfare benefits of our neediest citizens are arbitrarily terminated;244 where immigrants are deported without process; ${ }^{245}$ and when the homeless are left to fend for themselves, ${ }^{24}{ }^{6}$ our society has a problem that requires prompt correction.

242. We think the timing of our proposal may be particularly appropriate given a recent trend, at least in Congress, toward altering the existing regulatory regime with new legislative reforms. A few bills proposed in the summer of 2015 include: Smarter Regulations Through Advance Planning and Review Act of 2015, S. 1817, 114 th Cong. (2015) (which would require agencies to develop plans for retrospective review of new rules); Early Participation in Regulations

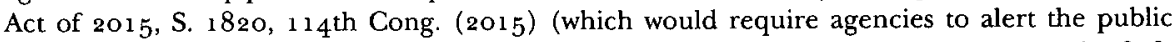
ninety days before publishing most draft rules); and Principled Rulemaking Act of 2015 , S. 1818 , $114^{\text {th }}$ Cong. (2015) (which would require agencies to consider alternatives to rulemaking and to tailor their rules to decrease concomitant burdens on society). Of course, our proposal is different from these bills, in the sense that we are less concerned with the socioeconomic burden of regulation and more concerned with correcting the democracy deficit and the human-rights abuses that may occur through agency contracting initiatives. But the proposal to increase public awareness of rulemaking is analogous to our call for greater public participation in privatization-and, more broadly, these and similar pieces of proposed legislation suggest that there may be an appetite in Washington D.C. (perhaps in some state capitals as well) to rethink some of our contemporary approaches to administrative governance.

\footnotetext{
243. See supra text accompanying notes $73-75$.

244. See supra text accompanying note 134 .

245. See supra text accompanying notes $120-22$.

246. See supra text accompanying notes $89-90$.
} 
By inviting the public into the outsourcing process, by establishing firm contractual baselines, and by ensuring that liability will attach where contractors breach, we can begin to reorient without unduly undermining the flexibility that contracts can provide. 


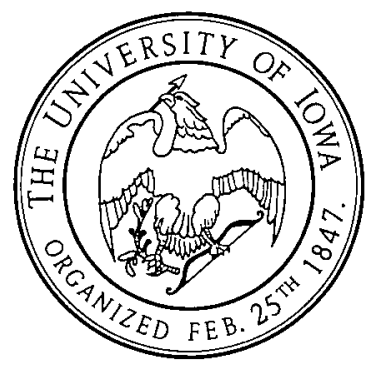

